
centrasiatiques et tibétaines

$51 \mid 2020$

Ladakh Through the Ages. A Volume on Art History and Archaeology, followed by Varia

\title{
Triloknath revisited. Recent results from field
} research

Nouveau regard sur Triloknath. Nouveaux résultats depuis le terrain

\section{Gerald Kozicz}

\section{(2) OpenEdition Journals}

Electronic version

URL: https://journals.openedition.org/emscat/4286

DOI: $10.4000 /$ emscat.4286

ISSN: 2101-0013

\section{Publisher}

Centre d'Etudes Mongoles \& Sibériennes / École Pratique des Hautes Études

Electronic reference

Gerald Kozicz, "Triloknath revisited. Recent results from field research", Études mongoles et sibériennes, centrasiatiques et tibétaines [Online], 51 | 2020, Online since 09 December 2020, connection on 13 July 2021. URL: http://journals.openedition.org/emscat/4286 ; DOI: https://doi.org/10.4000/emscat.4286

This text was automatically generated on 13 July 2021.

(C) Tous droits réservés 


\title{
Triloknath revisited. Recent results from field research
}

Nouveau regard sur Triloknath. Nouveaux résultats depuis le terrain

\author{
Gerald Kozicz
}

\section{AUTHOR'S NOTE}

For an explanation of the Sanskrit terminology on architecture used in this article and a selection of nagara temples from other districts of Himachal Pradesh see Nagara Architecture website at https://iam.tugraz.at/nagara/team.html (accessed 14 October 2020).

\section{General introduction}

1 Due to its geographical location and setting, the Chandrabhaga valley of Lahul has always been a transit region. It never developed a significant local dynastic or royal lineage of its own ${ }^{1}$. Over the centuries, it has come under the influence and control of various powerful neighbours. In the second half of the first millennium CE, Chamba and Kashmir exercised their powers over this part of the Western Himalayas, right at the gates of the Tibetan cultural and political sphere. At the turn of the first millennium, the Western Tibetan Kingdom of Guge and Purang established political control over the upper, eastern part of the valley above the confluence of the Chandra and the Bhaga rivers. Finally, from around $1200 \mathrm{CE}$ onwards, Ladakh extended its power to the south and seized the upper part of Lahul from Guge and Purang. The neighbours of Lahul not only had an impact on the military and political level, but also on the religious and cultural situation of this part of the Western Himalayas. While in Chamba various Brahmanical cults predominated, the rulers and elites of Kashmir supported both Hinduism and Buddhism². On the opposite side, the Tibetan sphere including Ladakh 
was clearly promoting a Buddhist religious agenda. These different and also changing factors have ever since reflected upon the religious landscape of the valley.

The village of Tunde is one of the most spectacularly situated settlements of the sparsely populated Chandrabhaga valley. It is placed at the very edge of a rocky spur on the northern face of the southern-most chain of the Western Himalayan Range. The green slopes towards the South are in sharp contrast to the steep cliff to its North that falls straight down into the Chandrabhaga river (fig. 1). Tunde is located at the junction of two ancient trade routes: one East-West connecting the then Buddhist regions of Western Tibet with Kashmir and Uddayana (modern Swat), and one leading from Chamba in the South to Zangskar, Ladakh and finally to Central Asia in the North. As early as the $8^{\text {th }} / 9^{\text {th }}$ century, a stone temple was erected at this spot where the trail over the Himalayan Range towards the ancient capital of Brahmapura (modern Bramour in Chamba) had its starting point ${ }^{3}$. This local temple is today known as Triloknath Mandir after its enshrined idol which is venerated as Siva Triloknath by the local Hindu population. It became one of the most important pilgrimage centres of the Western Himalayas. Its fame is such that the village is nowadays commonly referred to as Triloknath. Architecturally speaking, the Triloknath Mandir is the only temple that is of the most common type of North-Indian temple architecture (nagara style) that has survived - or perhaps has ever been built - in Lahul.

Figure 1. Tunde (also spelled Tonde) / Triloknath at the edge of a cliff above the Chandrabhaga River

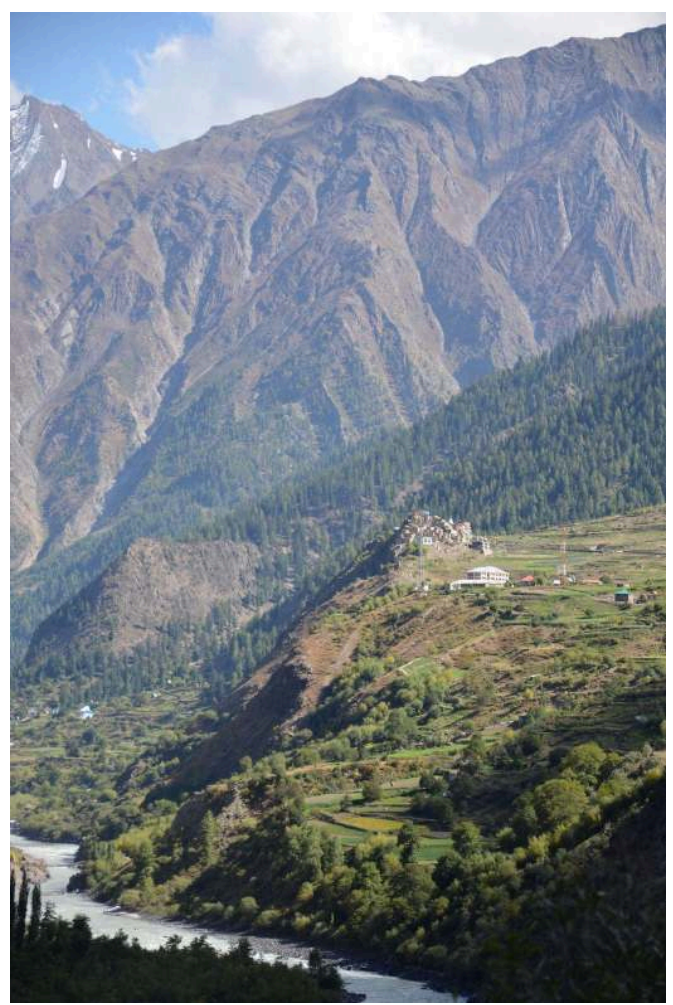

(c) Gerald Kozicz, 2017 


\section{Historical perspective}

3 The upper, eastern part of Lahul has been almost completely Buddhist since the times of the Guge and Purang kingdoms. The situation in the western, lower part of the Chandrabhaga valley is different. Two sites stand out from the otherwise Hindu sociocultural environment of Lower Lahul: the Triloknath temple at Tunde, and the Mirkulā Devi temple located in Udaipur on the northern banks of the Chandrabaga, some $15 \mathrm{~km}$ downstream from Triloknath. Both temples predate the Second Spread of Buddhism that took place around $1000 \mathrm{CE}$, and both are highly venerated by Hindus and Buddhists alike today. This local coexistence of the two religions results in the unusual practice of a double identity for the main deities of these temples. In Udaipur, the deity in the sanctum is clearly a Durga $\bar{a}^{4}$, but Buddhists venerate the figure as Vajravārāhī, while in Triloknath the main deity is a six-armed figure in seated position with the left leg pending down (Skt. lalitāsana) whose identity is not immediately clear. Hindu followers address the sculpture as Śiva Triloknath ("who controls the Three Worlds"), while adherents of Buddhism recognise it as Avalokiteśvara ${ }^{5}$.

This religious dichotomy or ambiguity has attracted much scholarly interest, focusing on the question of the original affiliation of the temple. The debate primarily centred on the identity of the main idol ${ }^{6}$. Only more recently have the architectural aspects been taken into account and investigated. In his 1980 article, Thomas Maxwell mentions a "spout" (Skt. pranala) at the northern face of the temple's pedestal (Skt. pitha) (fig. 2). As such spout would normally serve as an outlet for the liquids poured over the symbolic, phallic representation of Śiva (Skt. lingam), in the sanctum, Maxwell identifies the main deity as Śiva Maheśvara and the temple overall as a Śaiva monument. He also notes that "a stone śikhara [curvilinear tower] like this belongs far to the South, at much lower levels, down in the Kulu valley and on the plains beyond, not among the snows of Indian Tibet"7. Further, Maxwell notes the Three Faces of Śiva (Skt.trimukha) inside the central dormer window on the sukanasa, the upper architectural member of the portal (fig. 3). More recently Verena Widorn highlighted the presence of two Buddha figures on the capitals of the temple's porch ${ }^{8}$ (fig. 4). As can be ascertained by comparison with other nagara temples such as the Gauri-Śankara temple of Dashal in the neighbouring region of Kulu, the nature of deities placed in such position also indicates the nature the temple as a whole (fig. 5). Widorn therefore identified the deity as Sugatisamdarśana Lokeśvara and argued for a Buddhist foundation. We will return to the question of the significance of the pranala further below. 
Figure 2. Pranala emerging from the pedestal below the central northern projection (Skt. bhadra) and niche

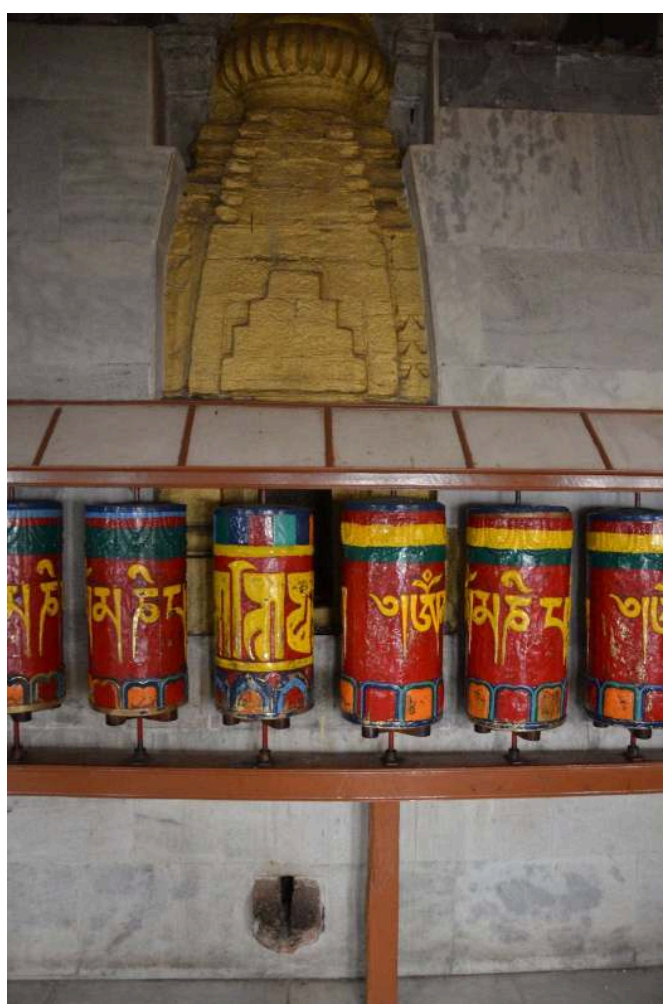

(c) Gerald Kozicz, 2017

Figure 3. The Three Faces of Śiva on the śukanasa

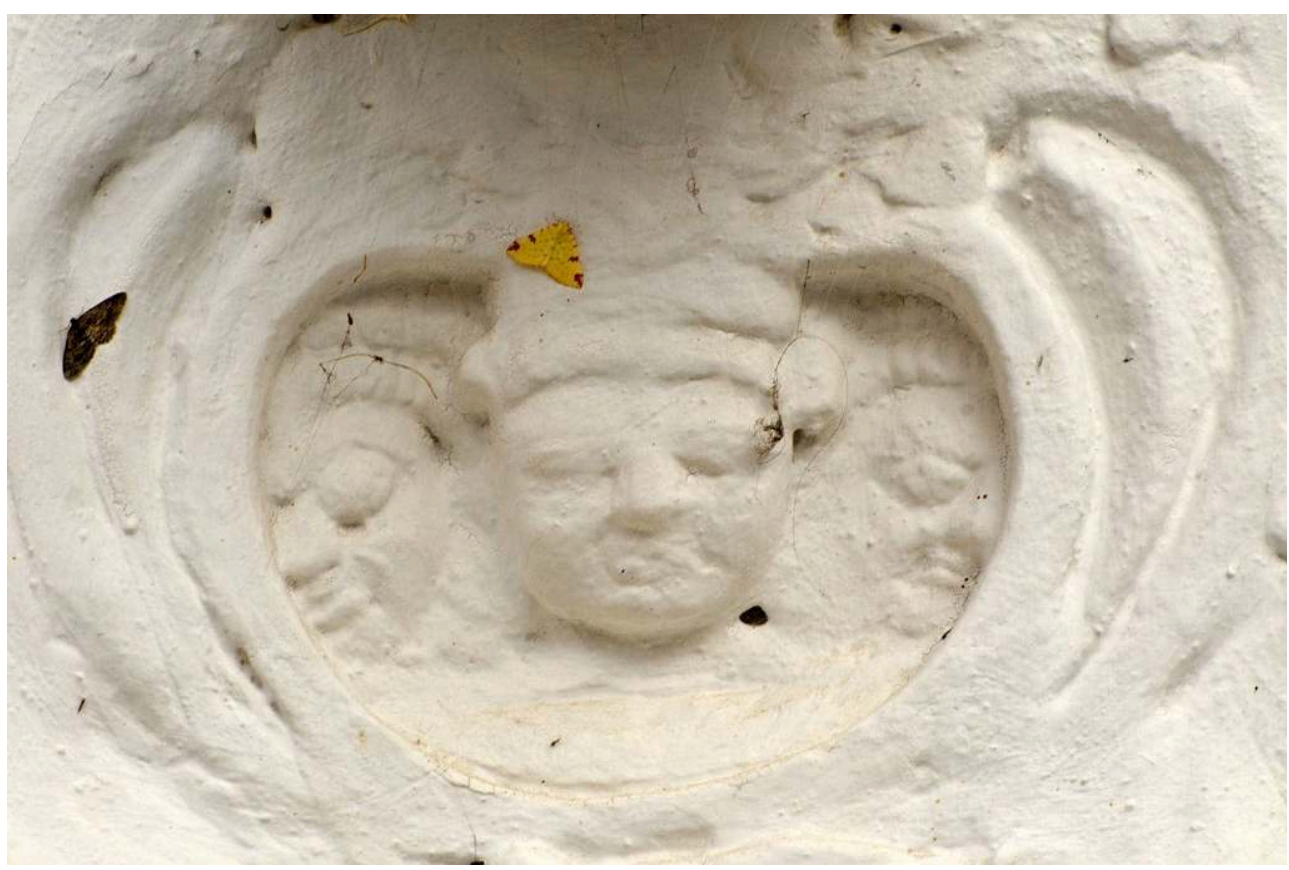

(c) Rob Linrothe, 2018 
Figure 4. Seated Buddha of the capital at Triloknath. Note the lion face ("Face of Glory", Skt. kirttimukha) in the centre of the architrave

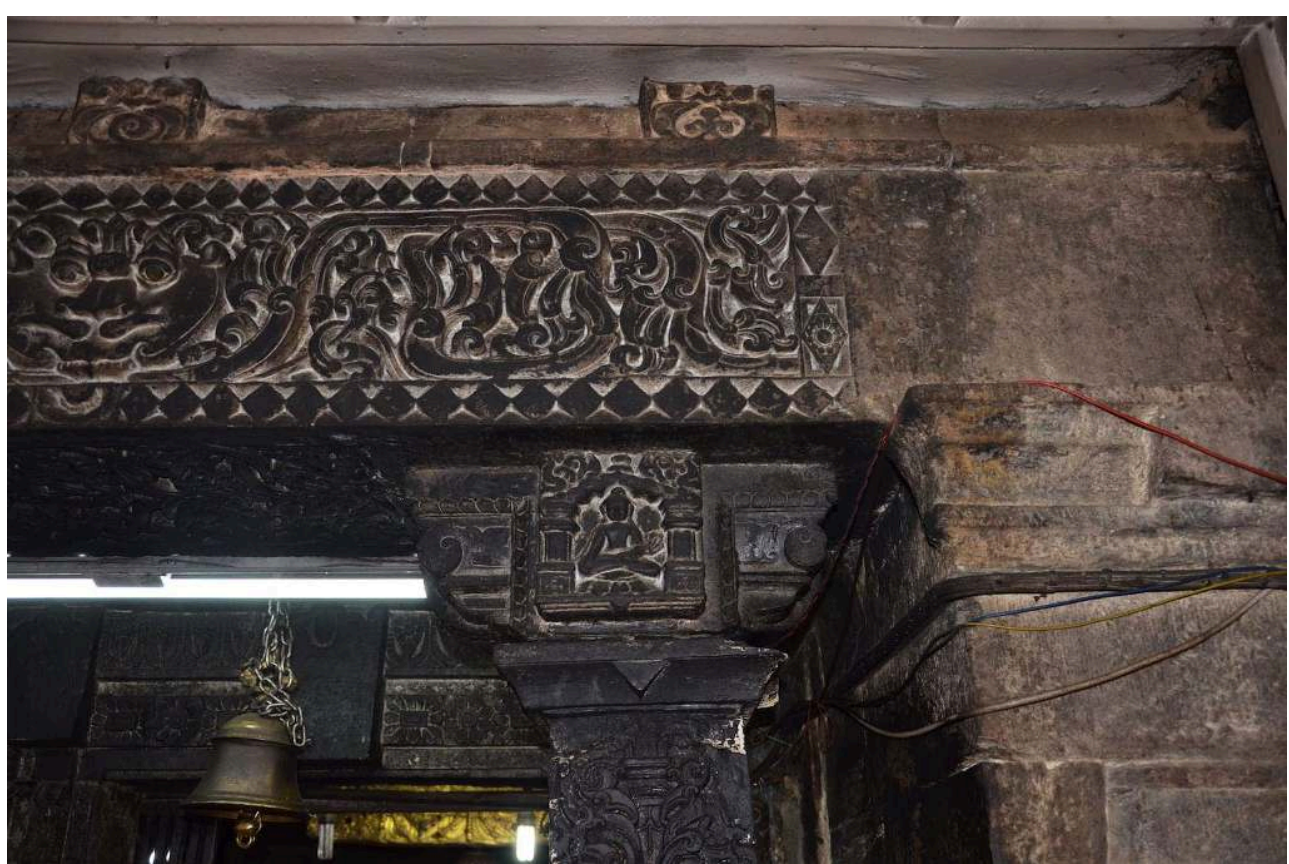

(c) Gerald Kozicz, 2017

Figure 5. Gaurī-Śaṇkara (Śiva and Pārvatī) in the centre of the architrave flanked by Brahma to their respective right on the capital and Vișnu on the capital to their left at the Dashal Gaurī-Śankara temple

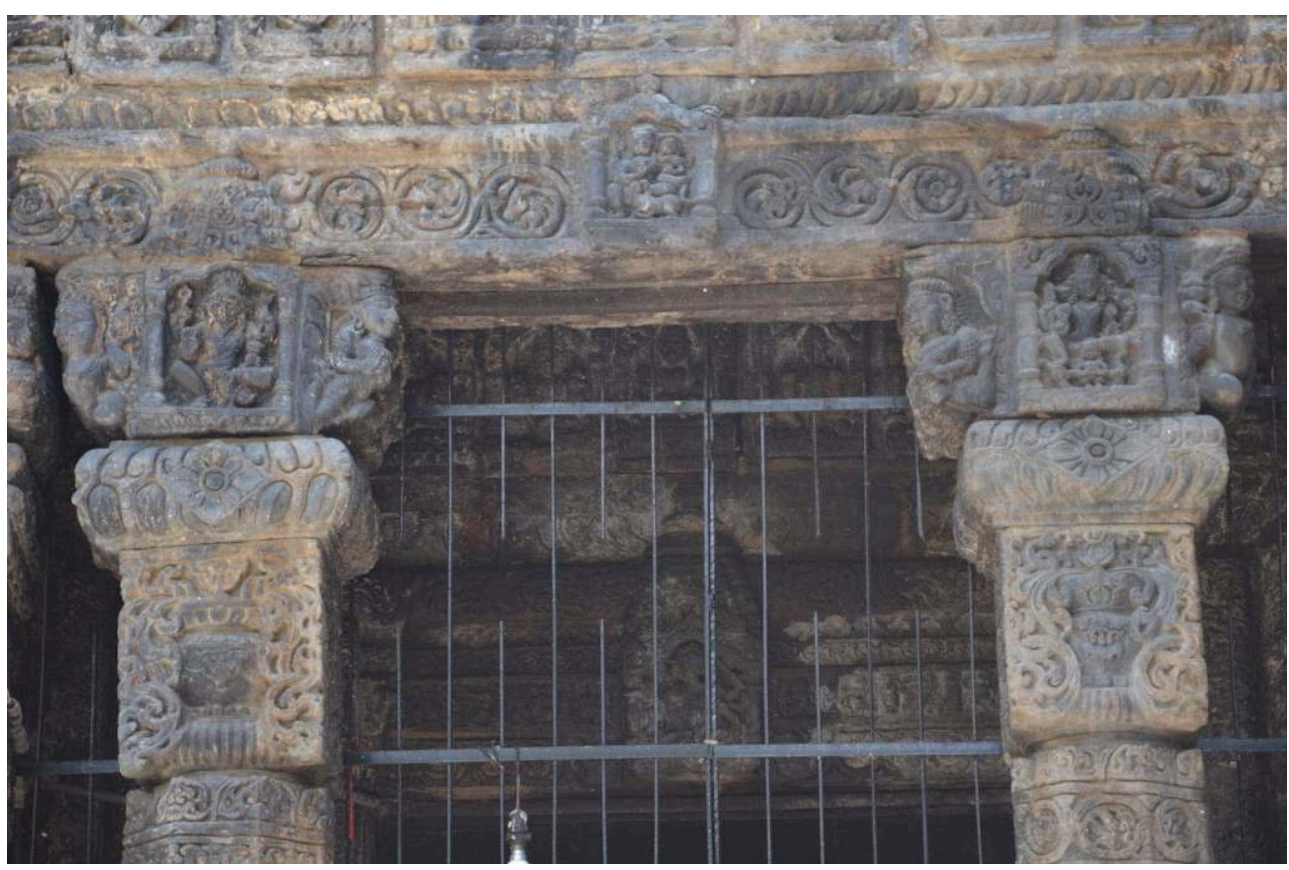

(c) Gerald Kozicz, 2014

5 Apparently the structural evidence supports both views, since neither the pranala nor the porch capitals appear to be later additions. The finding of a donor inscription inside the temple seemed to solve the conflict, as it ascribed the foundation of the temple to a 
Buddhist donor who also became the first priest of the temple9. However, as the decades-long debate about the dating of the famous Alchi Sumtsek in Ladakh has shown, inscriptions do not constitute secure evidence unless their status as a member of the original construction of the building can be ascertained ${ }^{10}$. Accordingly, both the sculpture (as a classical example of portable art) and the inscription cannot be considered as unquestionable evidence for the temple's original affiliation. Therefore, the current essay focuses on the architectural data collected in 2016 and 2017, as well as on comparative material gathered during a survey of the monuments of Chamba Town in 2018.

6 The major question, which will be addressed in the following, is therefore not about the identity of the deity, but the architectural evidence and the architectural history of the building. The article also seeks to provide clues for the explanation of the peaceful coexistence of Hindu and Buddhist practices. The re-use or incorporation of a site or of a specific piece of religious art into a new context is not at all unusual in India ${ }^{11}$. But such a move usually reflects a change of the religious context or a re-programming of a site. No such strategy however can be noted at Triloknath. A photograph from 1980 shows a Hindu "priest" (Skt. püjāri) as caretaker sitting in front of the "vestibule" (Skt. antarāla) at Triloknath, while in 2006 a Buddhist lama was performing the rituals for both Hindu and Buddhist pilgrims (fig. 6). In 2016, a lama and a priest were in charge of the temple, changing their positions inside the sanctum in accordance with the religious affiliation of the respective devotee (fig. 7). Such peaceful coexistence is quite exceptional and will therefore be paid specific attention to in the following.

Figure 6. Vestibule during the most recent renovation displaying the original elongate form of the bases of the columns

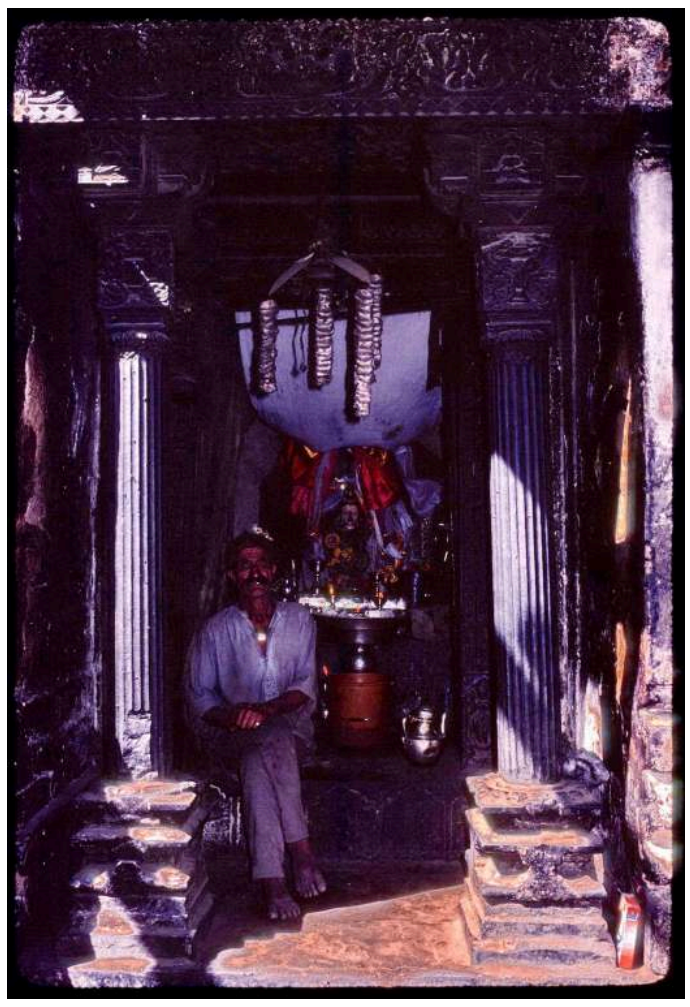

(c) Heinrich Pöll, 1980 
Figure 7. The portal and the chamber viewed from the modern mandapa (ante-space or hall in front of the vestibule)

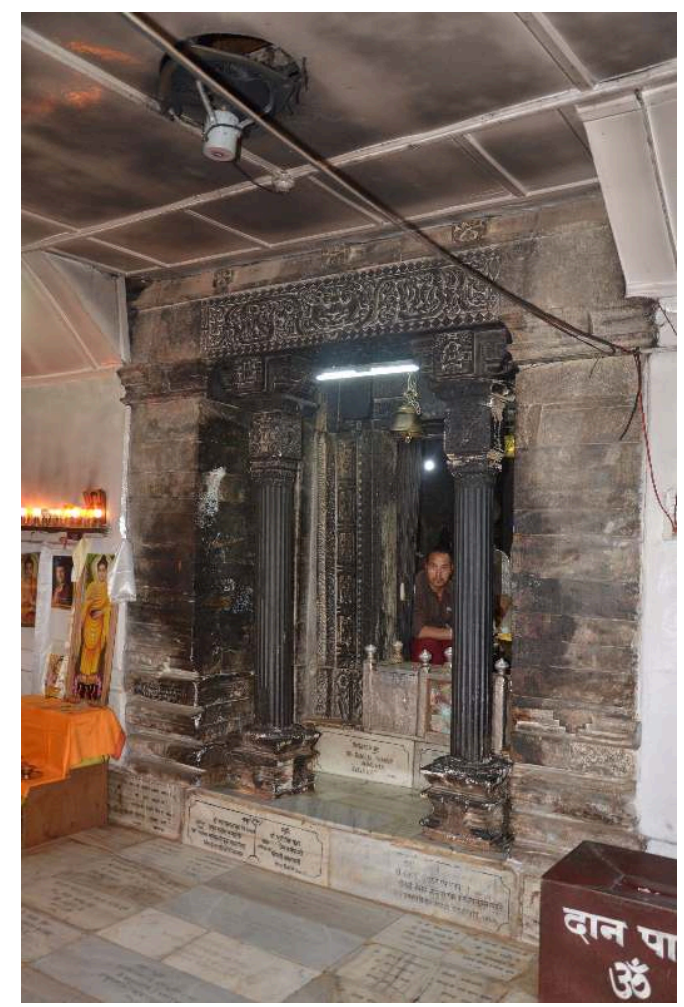

(c) Gerald Kozicz, 2017

\section{Architectural documentation and analysis}

7 The temple of Triloknath is the only nagara temple in the Chandrabhaga valley. Its major architectural parts are the sikhara tower above the mandovara, the actual shrine that includes the sanctum (Skt.garbhagrha), and the portal with the vestibule. The sanctum is of the usual square plan with two projections in each direction on the outside. Two projections from the basic cube result in three layers altogether and a cruciform trianga floor plan (fig. 8). The śikhara tower is topped by a notched stone disk (Skt. ämalaka) (fig. 9). Since the monument had been severely hit by avalanches and landslides several times in the past, the whole structure has certainly undergone major restoration work and structural changes ${ }^{12}$. The most significant alteration to the main building was the mantling of the whole mandovara with marble finishing. Today, only the three central bhadra niches and the entrance area are visible. In addition, a modern "ante-chamber" (Skt.mandapa) was erected and a roofed corridor for "circumambulation" (Skt. pradakșināpatha) was built around the whole structure. It is therefore now impossible to view the temple in its original form. 
Figure 8. Floor plan displaying a square sanctum with a vestibule as well as offsets with bhadra niches at the centres of the outer wall

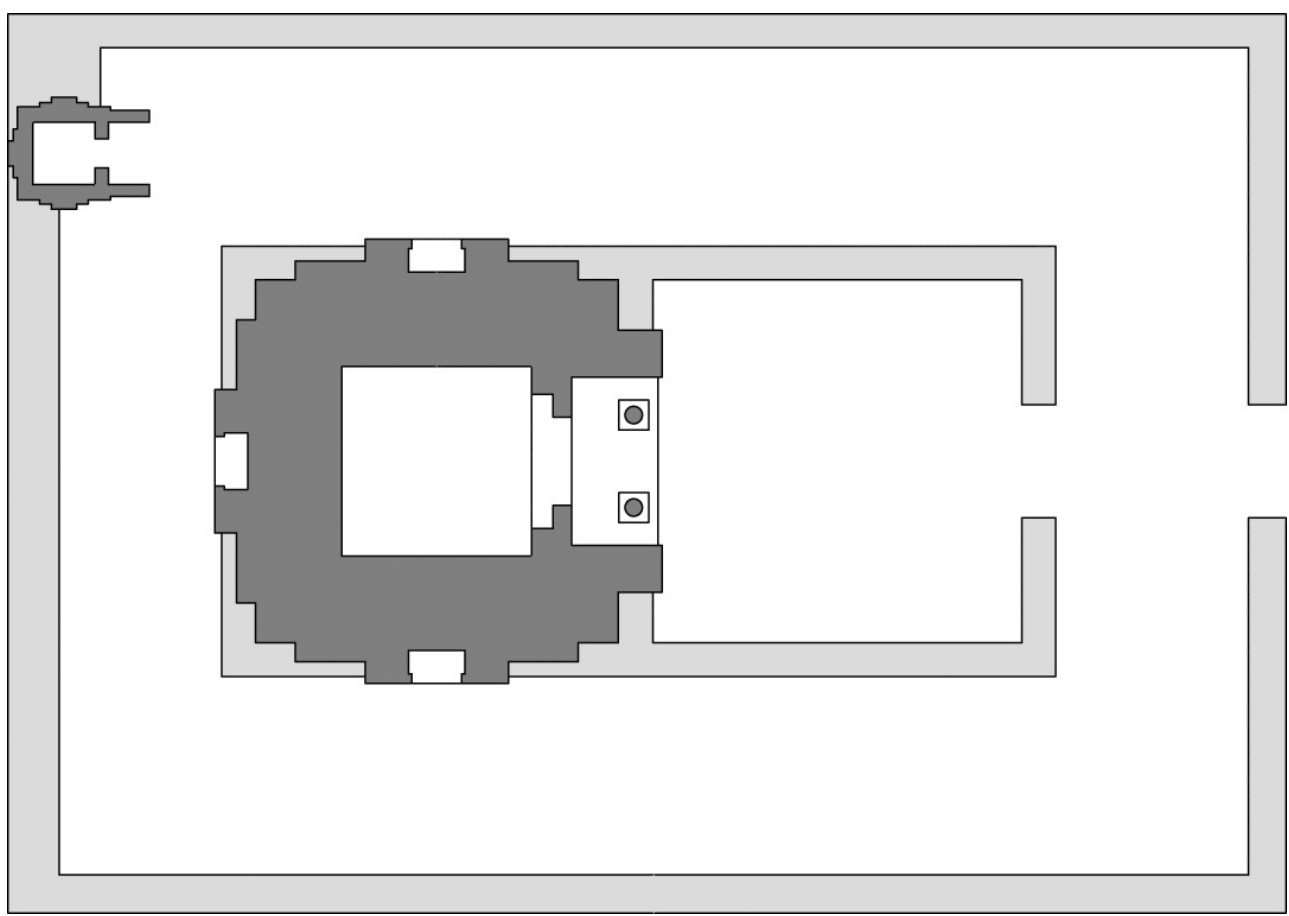

Note the modern mantling of the corner areas which turned the original cruciform outer shape almost into a square (see also fig. 2 where the modern white marble finish is clearly shown)

(c) Gerald Kozicz, 2017

Figure 9. View from the yard

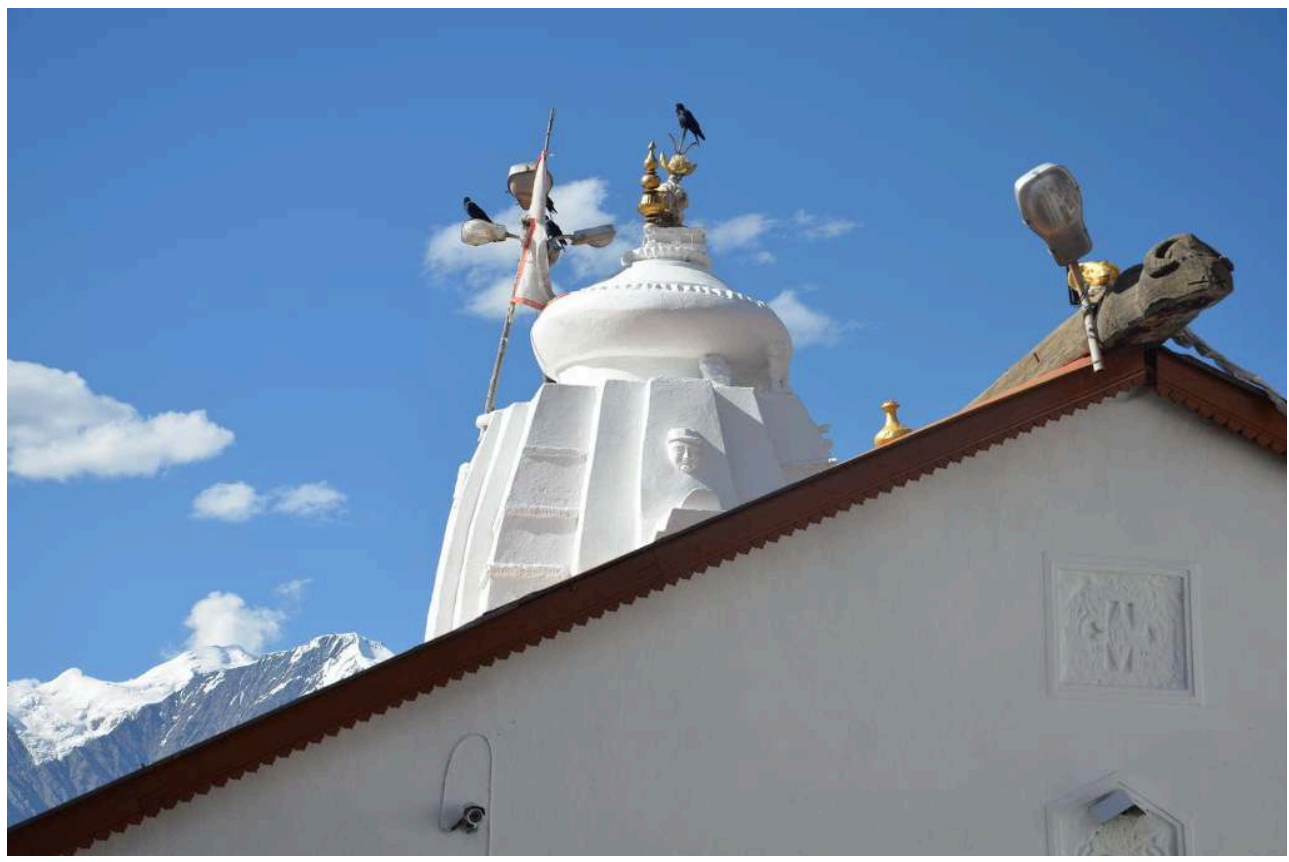

(c) Gerald Kozicz, 2017

8 As noted above, Maxwell argued for a Śaiva affiliation of the temple on the basis of comparisons with nagara temples in Kulu. Although Maxwell's conclusions appear 
sound, new evidence recalls for a re-evaluation of their validity. First of all, the śikhara tower as it appears today has a surface of white plaster. The only visual features that are visible are the vertical structure resulting from the cruciform, floor plan, four faces in high relief placed towards the cardinal direction plus the Three Faces of Siva motif on the śukanasa, and the corner āmalaka arranged in vertical order along the corners. A photograph taken during repair works in 1980 (fig. 10), when the tower was without plaster, shows layers of brick-sized stones which had only been roughly treated. A sikhara built of undressed stones would not remain without plaster finishing as such irregular stone surfaces would not conform to the aesthetic standards of religious architecture. By contrast, contemporaneous nagara temples of Kulu were made of carefully chiselled large-size stone slabs and decorated with deep relief "dormer window" (Skt. gavākșa) (figs 11, 12). Likewise, the āmalaka of all Kulu temples were made from a huge, single stone block, while at Triloknath the ammalaka was again built up with small stone slabs. Afterwards plaster was applied again - only in this case the ammalaka retained its plain, bun-like shape without further formal features. The result was different from the typical àmalaka design of an abstract variant of a lotus flower.

Figure 10. Śikhara tower during renovation works following a disastrous landslide

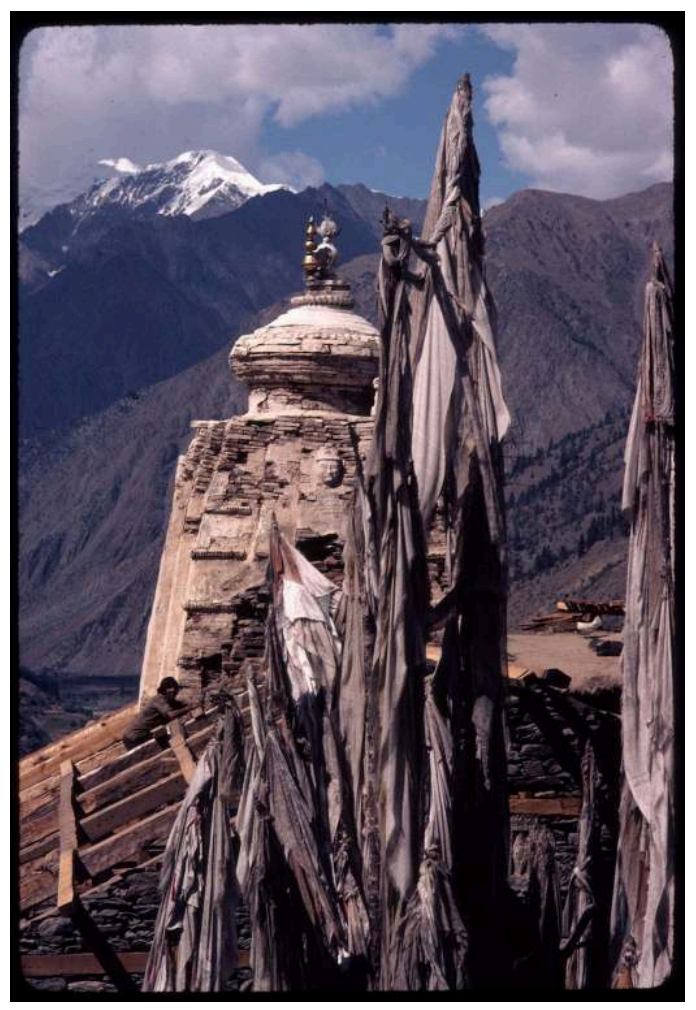

(c) Heinrich Pöll, 1980 
Figure 11. Śikhara tower and mandovara of Dashal

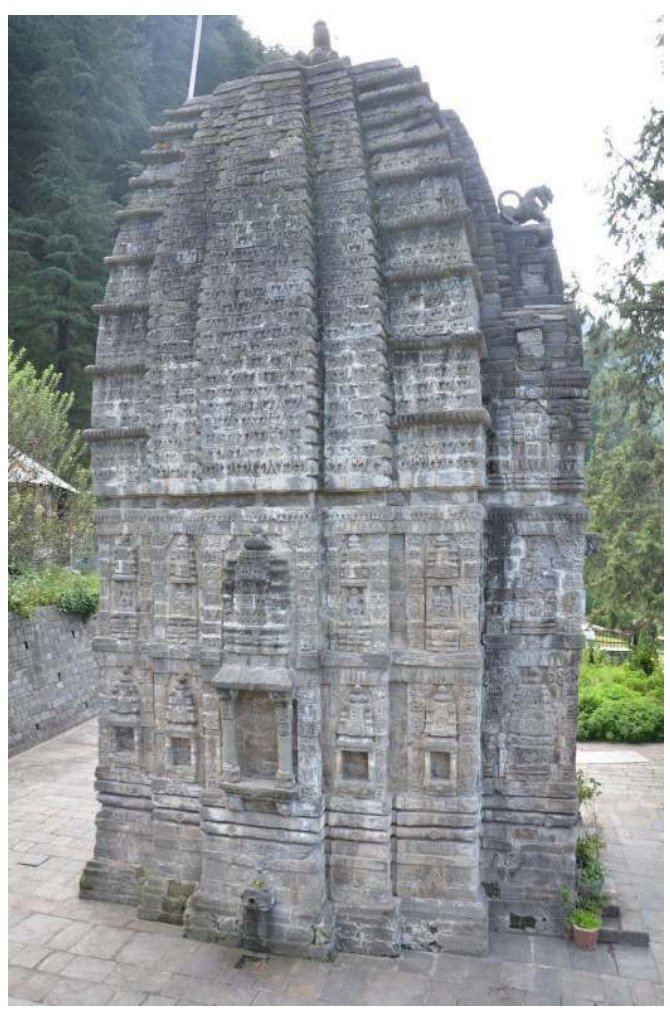

(c) Gerald Kozicz, 2017

Figure 12. Dormer window motifs on the śikhara tower of Gaurī-Śankara temple at Jagatsuk

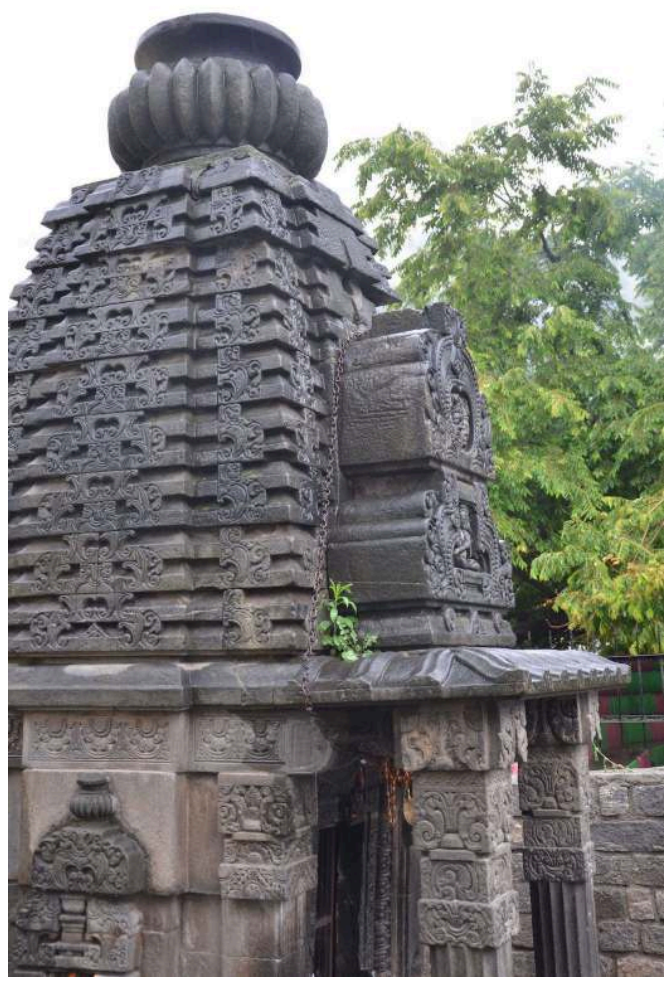

(c) Gerald Kozicz, 2014 
Another significant difference is visible on the sikhara above the bhadra proliferation. In Kulu there is always a clear separation between the mandovara and the sikhara tower, a deep recess or demarcation line (Skt. kanta), so that the śikhara appears like a separate architectural component. In contrast, at Triloknath pseudo-sikhara forms in high-relief extend from the bhadra niches beyond the kanta, each with a high-relief head in its upper part (see figs 9, 10). Both in its construction and its decoration, the Triloknath shrine thus significantly differs from the Kulu temples.

The architectural particularities and unconventional aspects of the temple continue on the mandovara level, which was built in stone. Other than with the sikhara, here largescale stone slabs had been carefully chiselled according to the general construction principles of nagara stone temple architecture. During the last decade, all niches have been regularly painted in gold but none of the parts visible today has ever been covered with plaster. Each of the three bhadra projections was done as a high relief, mirroring a miniature nagara temple with an elongated śikhara. Although there seems to be nothing specific in this composition at first sight, it differs in several aspects from all the nagara temples of Kulu. Normally, the relief frame of a bhadra niche projects forward from the facade beyond all other parts of the building. At Triloknath this rule is not followed. This is clearly visible in the uppermost parts of the bhadra relief - a sikhara tower with a double-āmalaka - where they actually extend into the central shoulders of the sikhara tower and literally cut through the cornice. Therefore this lowest part of the upper shoulder appears like a niche for the bhadra śikhara motifs.

11 Maxwell's conclusions are questionable mainly because he focused on the wrong region in search for comparative monuments. A close inspection of the architecture of Chamba provides us with a slightly different picture (fig. 13). 


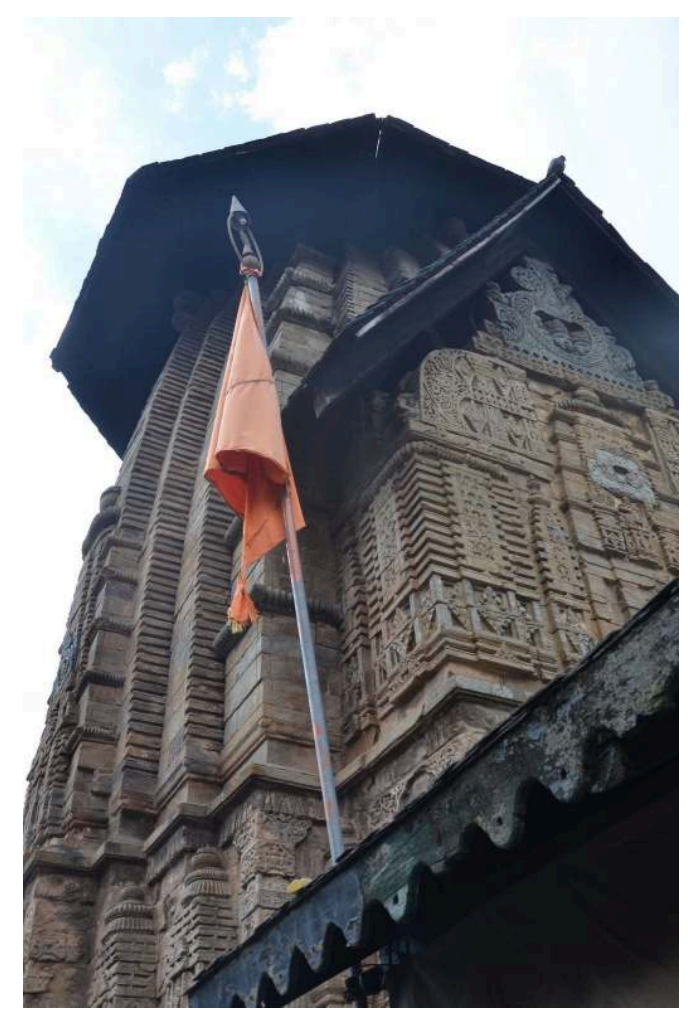

(c) Gerald Kozicz, 2018

12 A comparison with the Hari Rai temple, the Chamesan Bhagvati temple and the Viśnu temple of the Lakśmi Narayana Complex of Chamba Town, where the Brahmour Kings moved their capital in the $9^{\text {th }}$ century, displays several similar patterns. The sikhara tower of Hari Rai temple shows no dormer window motifs, and above the bhadra proliferations of that temple we again find an extension of the central niche beyond the kanta (fig. 14). This close relation between Triloknath and the early nagara temples of Chamba is not a surprise, since the kingdom of Brahmapura, from which Chamba emerged, was once in control of that part of the Chandrabaga valley. While the design principles of the Triloknath shrine and the Chamba temples are similar, the building material and the construction methods of the sikhara again differ. The towers of the Chamba temples - like in Kulu - were all made of precisely chiselled stone slabs without further application of plaster. 
Figure 14. Elevations in comparison: Chamasen Bhagvati temple of Chamba Town, and Dashal Gaurī-Śaṇkara temple

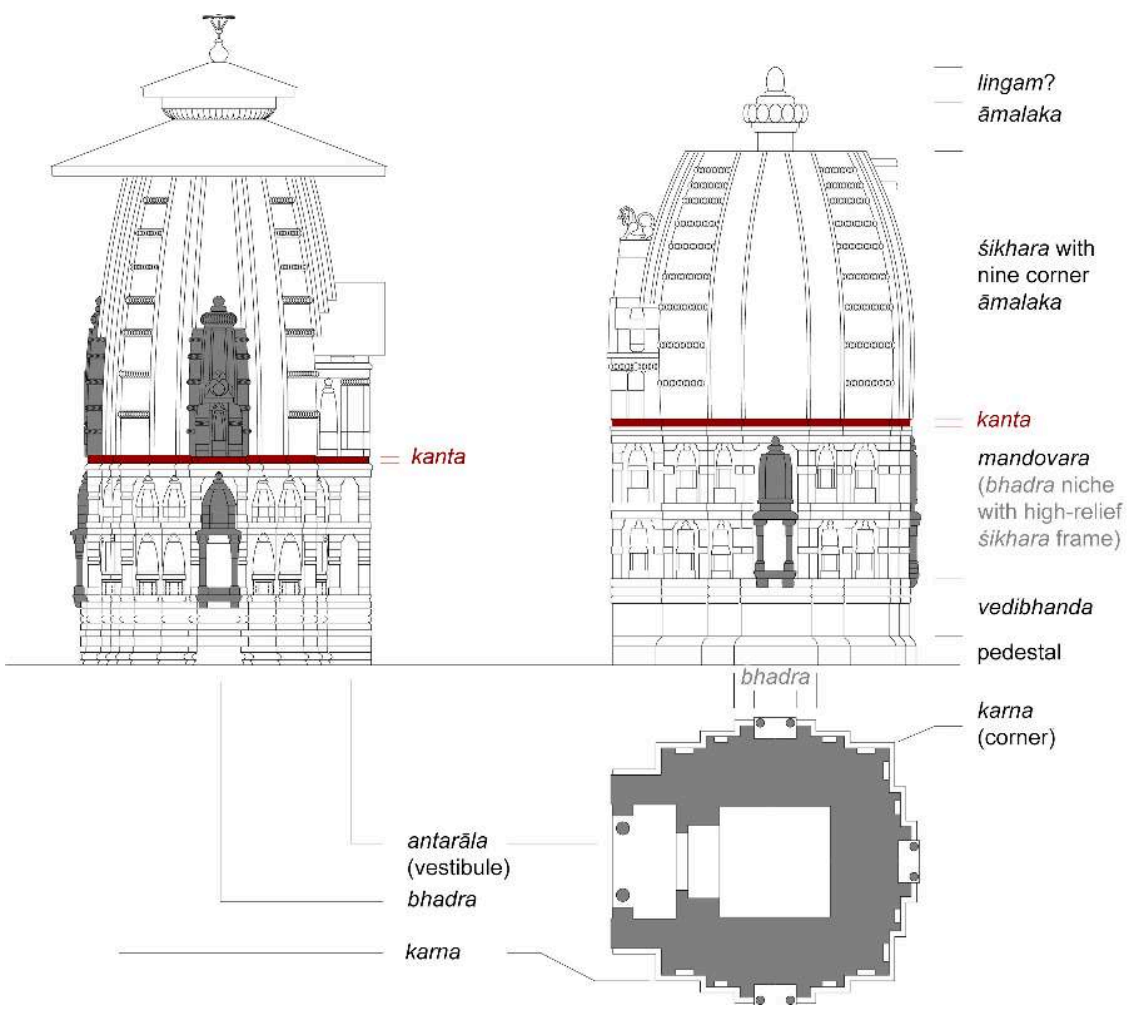

(c) Gerald Kozicz, 2018

13 A distinctive feature at Triloknath is the square frame that surrounds the actual bhadra niche. In all contemporaneous Kulu and Chamba temples, the vertical elements were of the form of pilaster-like columns or even fully developed columns detached from the bhadra. Only at Triloknath they resemble actual doorframes with lintels, threshold and jambs (fig. 15). In Kulu, such compositions are only found at temples with full size lateral chambers with actual gates such as the temple of Bajaura. 
Figure 15. Gilded jamb bhadra niche frame of the Triloknath temple

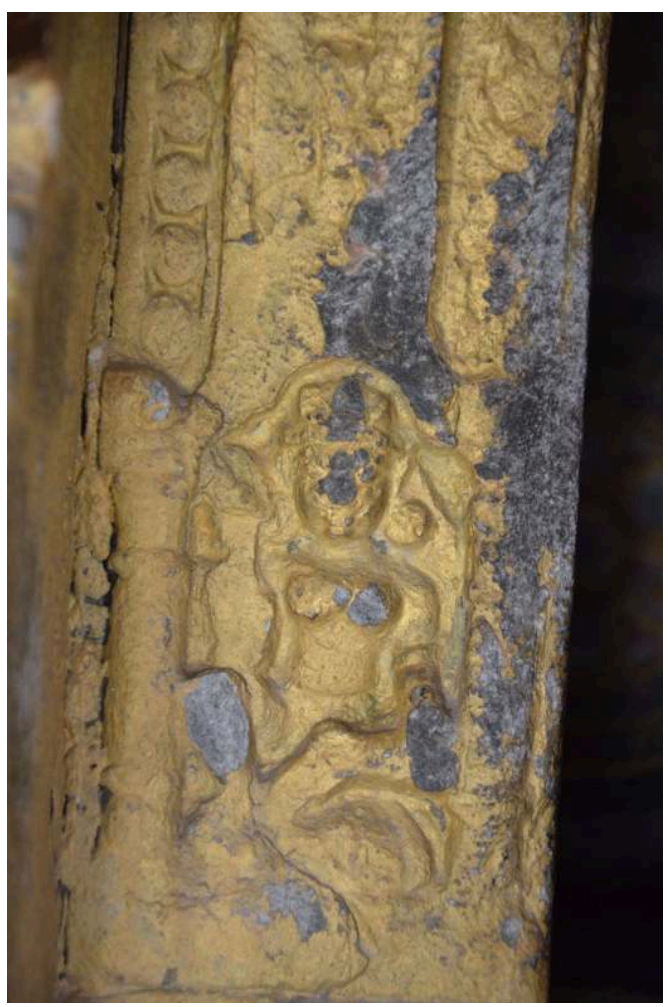

(c) Gerald Kozicz, 2017

14 While the architectural evidence discussed so far clearly contradicts Maxwell's conclusions, two pieces of evidence brought forward in his article still appear undisputable: the Three Faces of Siva and the pranala. But, then again, a close inspection of the prototypical temples of Chamba Town mentioned above yields a more nuanced picture. Both the Hari Rai temple and the Viśnu temple of the Lakśmi Narayana Complex, which have so far been dated to around the turn of the first millennium, are dedicated to Viśnu ${ }^{13}$. Nevertheless, both show the Three Faces of Śiva images inside the sunken medallion of the sukanasa - and both have a pranala (fig. 16). These features are even found on the Chamasen Baghvati temple and the nagara temple of Mela - about $10 \mathrm{~km}$ from Chamba Town and known as Hidimba Mandir - both of which are dedicated to Durga. In fact, there is not a single nagara temple in Chamba so far visited by the author that is without these elements - no matter which cult is practised and to which deity the monument has been dedicated ${ }^{14}$. Evidently, the use of these components in nagara architecture was generic, and a pranala does therefore not necessarily indicate a Śaiva affiliation of a monument. Since we do not know what the Buddhist temples of the wider Chamba region looked like due to lack of archaeological evidence, and what kind of rituals had been performed in these border regions of the Indian cultural sphere, it cannot be ruled out that Buddhists also adopted the same architectural concepts for their religious practices. 
Figure 16. Chamasen Bhagvati temple of Chamba with pranala and high-relief miniature temples extending beyond the kanta

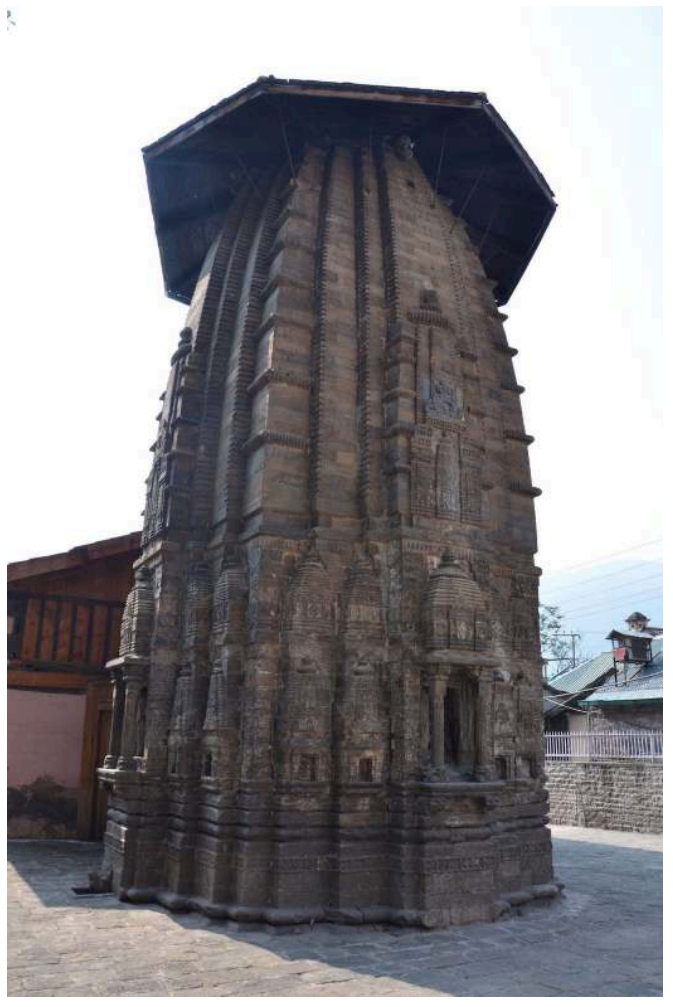

(c) Gerald Kozicz, 2016

\section{The portal: the frame and its centre}

The portal of a nagara temple is the major component of its built architecture. If we leave aside the meaningful but invisible aspects of a building, such as the mandala grid upon which the whole structure had been planned and constructed, the gate is certainly the crystallisation of the essence of the monument. In the case of Triloknath, the portal consisted of the vestibule and the actual door frame. The vestibule served as a sort of porch to the gate - a spatial link between the profane and the sacred. It measures approx. 1,80 x 0,90 m (width/depth), or a ratio of 2:1. Its major components are the two fluted columns placed at a short distance from the lateral walls, and the massive architrave ${ }^{15}$.

16 As with all other nagara temples, the actual doorframe occupies the whole front of the sanctum between the lateral walls of the vestibule. The door opening measures $1,65 \times 0,88 \mathrm{~m}(\mathrm{~h} / \mathrm{w})$, again a ratio of $2: 1^{16}$. Structurally, the portal consists of the lintel, two vertical slabs and the horizontal slab at the bottom, which also serves as the threshold. Regarding the iconographic programme, the lateral slabs were chiselled to imitate a multi-framed gate composed of five vertical components (Skt. śäkhās) thereby probably following earlier models developed in wood, of which only a small number have stayed intact, such as the portal of the Deccani Mahādeva temple at Nirmand in $\mathrm{Kulu}^{17}$. The ornamental structure continues along the lintels of the doorframe, from which three small niches project, one in the centre and two in flanking positions right above the two inner jambs. Naturally, those three fields had 
been reserved for a triad of deities, which should directly reflect the religious concept and doctrinal affiliation of the temple, since-according to a basic rule in Indian architecture - the central image of the first lintel (Skt. lalātabimba) represents the deity to whom the sanctum is dedicated. Religious affiliations of temples and even identities of deities may change, portable idols can be replaced, names of sites may be converted, and even inscriptions on walls might be added at a later point. But the carving on a lintel of stone could never be changed or re-done. The central image of the first lintel thus provides the only irrefutable proof of the original dedication of the monument ${ }^{18}$. Strangely the central image of the first lintel as well as the two flanking fields are blank at the Triloknath lintel ${ }^{19}$. Only some lines indicating trefoil-shaped silhouettes of pseudo-architectural frames are visible.

A common explanation for blank fields would be that the figures had been erased. But if that had been the case here, the relief of the central image of the first lintel would have projected much more widely from the surrounding ornaments than usual. One can therefore wonder, were the fields actually never carved? A small detail that was noted in the course of a re-examination of the photographic documentation sustains this hypothesis. One of the columns displays a horizontal line that marks the position of the central ring usually designating the middle of each column (fig. 17). The lines marking this ring would only be visible in the high relief and are therefore only visible along the projecting surface of the column. It would never be visible if the relief had been erased. This line is definitely a compass line and we may therefore conclude that the central image of the first lintel field was not erased but never carved. This hypothesis finds further support by the incomplete carving of the floral motif on the inner section of the first lintel. Only parts on the right, i.e. to the left of the deity, were completed (fig. 18). In fact not only the three fields but also some parts of the ornamentation were left incomplete. The evidence points to an abrupt halt of the construction.

Figure 17. Lintel, left side (viewer's perspective)

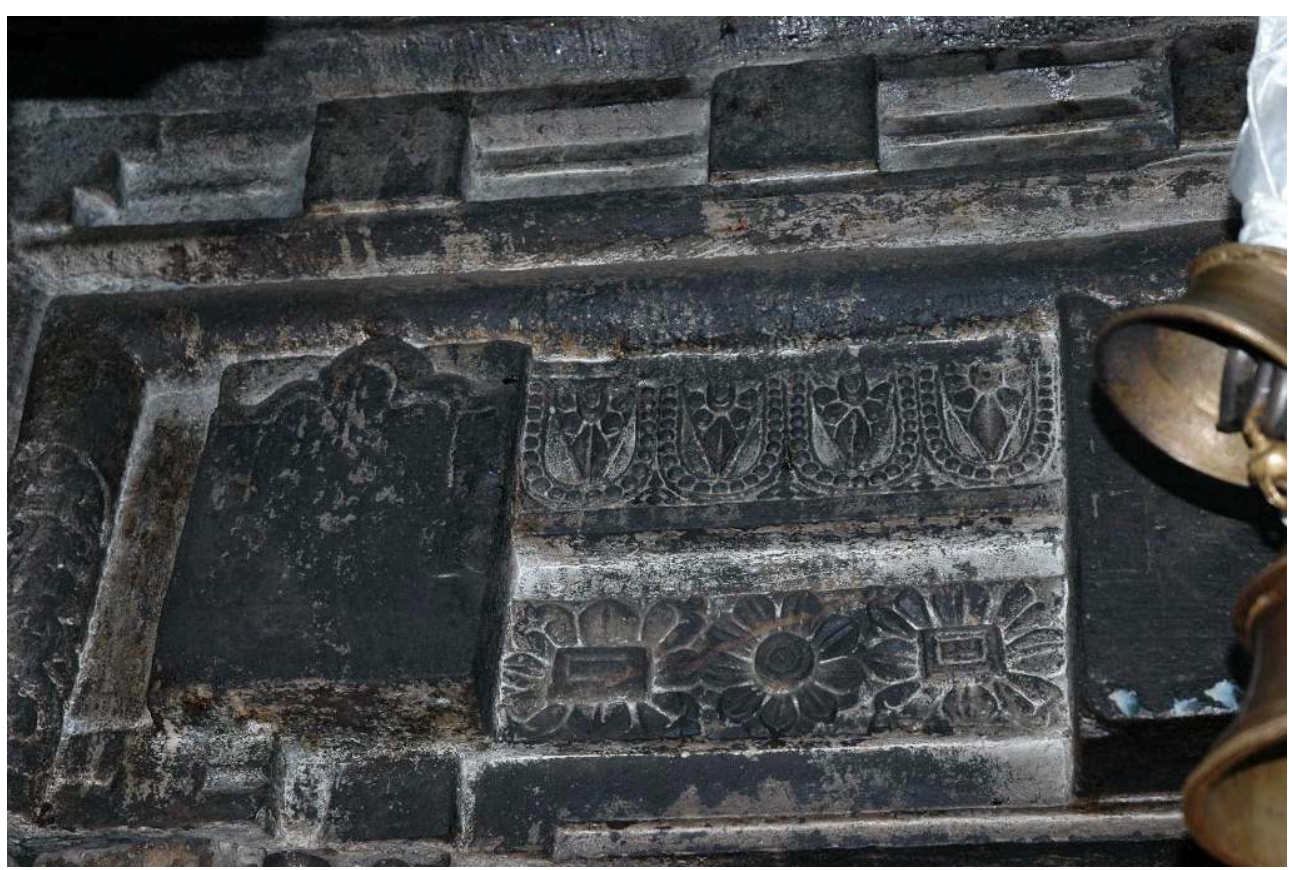

(c) Gerald Kozicz, 2006 
Figure 18. Lintel, right side

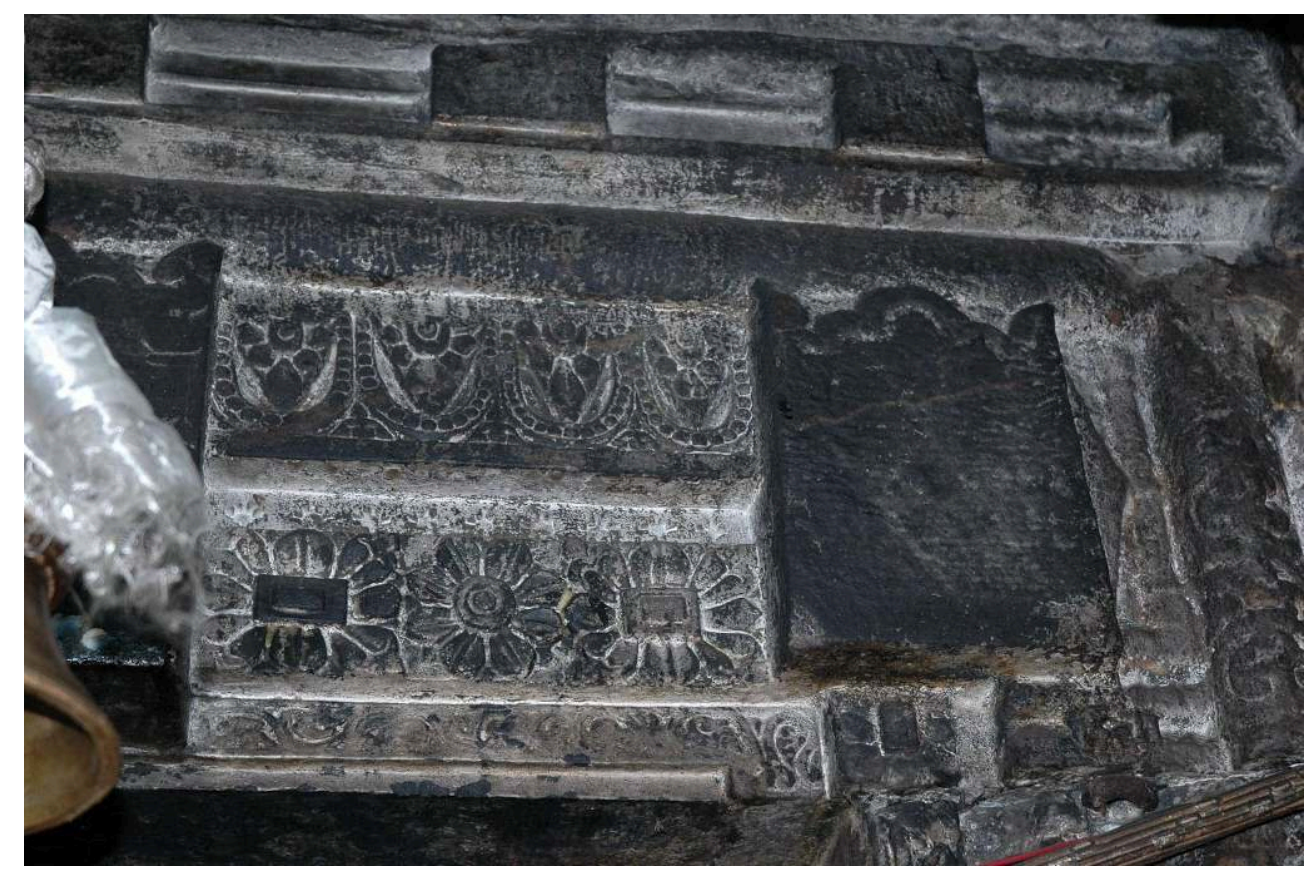

(c) Gerald Kozicz, 2006

19 By contrast, the decoration of the jambs seems to have been completed, comprising the depiction of the river goddesses Gangā and Yamunā and their accompanying guardians, and a set of ten female dancers or musicians who were placed inside separate architecture-like compartments (fig. 19). The river goddesses are standard members of the iconographic repertoire of Indian temple architecture and can be found on the doorframe of almost every Hindu temple. They were even incorporated in several doorframes of early Buddhist temples of Guge and Purang, such as on the wooden portal of the now demolished temple of Gumrang in the upper part of Lahul ${ }^{20}$. The identity of the ten dancers is not clear at all (fig. 20). A group of ten maidens is a common feature as an entourage of Pārvatī, the wife of Siva ${ }^{21}$. If this was actually the case, then it would certainly support Maxwell's conclusion about a Siva background. But even if those female dancers and musicians had originally been the maidens of Pārvatī's entourage, they could also have been incorporated into a Buddhist context in a similar act of cross-borrowing as with the integration of Siva's attributes in the iconography of Siṃhanādha Avalokiteśvara. 
Figure 19. Portal, plan displaying the evidence for incompleteness in red lines

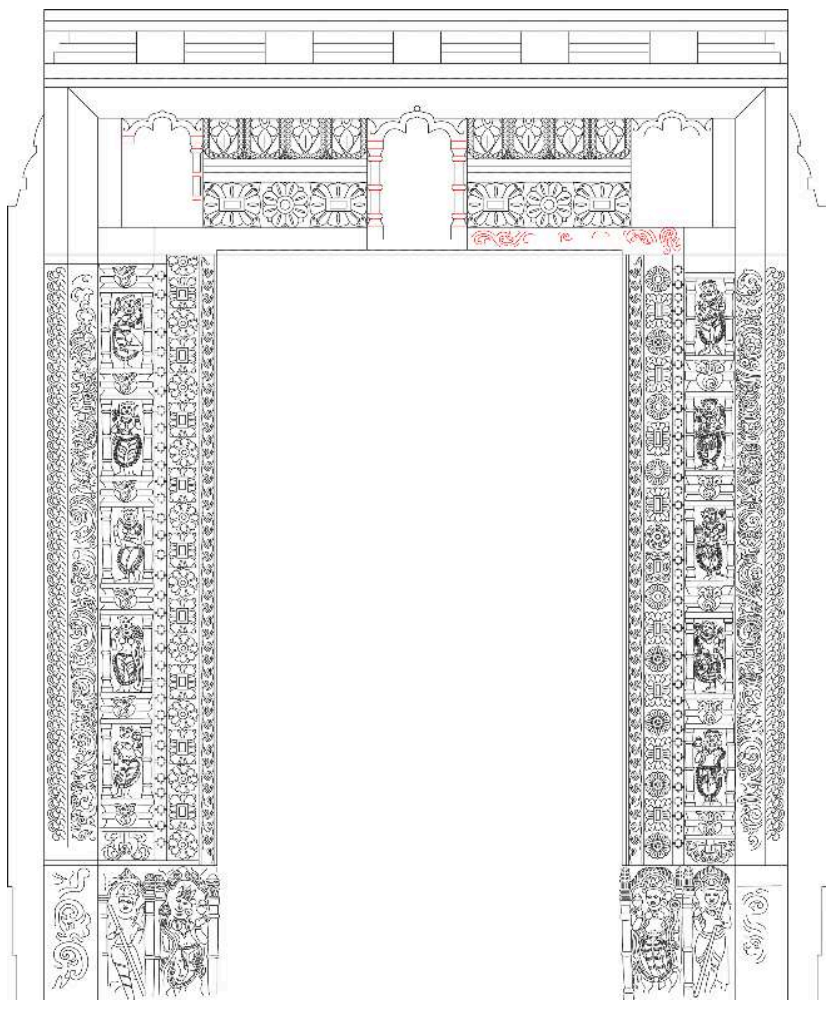

(c) Gerald Kozicz, 2016

Figure 20. Dancer on the jamb and river goddess Gangā at the bottom of the jamb

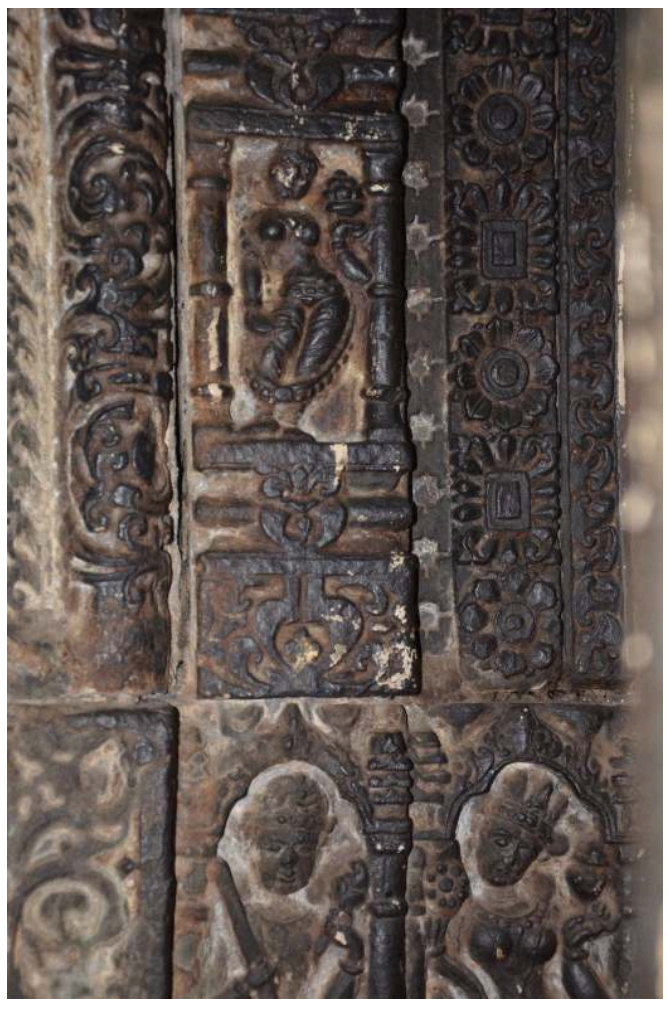

(c) Gerald Kozicz, 2017 
Basically, the design of the Triloknath portal corresponds to the Chamba temples. However, a significant difference must be noted among the decorative patterns of the vestibule. At all Chamba temples a vertical pilaster-like structure is found on the lateral walls just behind the columns. Arranged in vertical order, another set of river deities and other protective deities or semi-gods was depicted on those pilasters (fig. 21). The same iconographic configuration can also be found at the Dashal Gaurī-Śankara temple in Kulu. By contrast, the lateral walls at the Triloknath temple are plain.

Figure 21. Vestibule of Hari Rai temple with figures in vertical order behind the column on the lateral wall

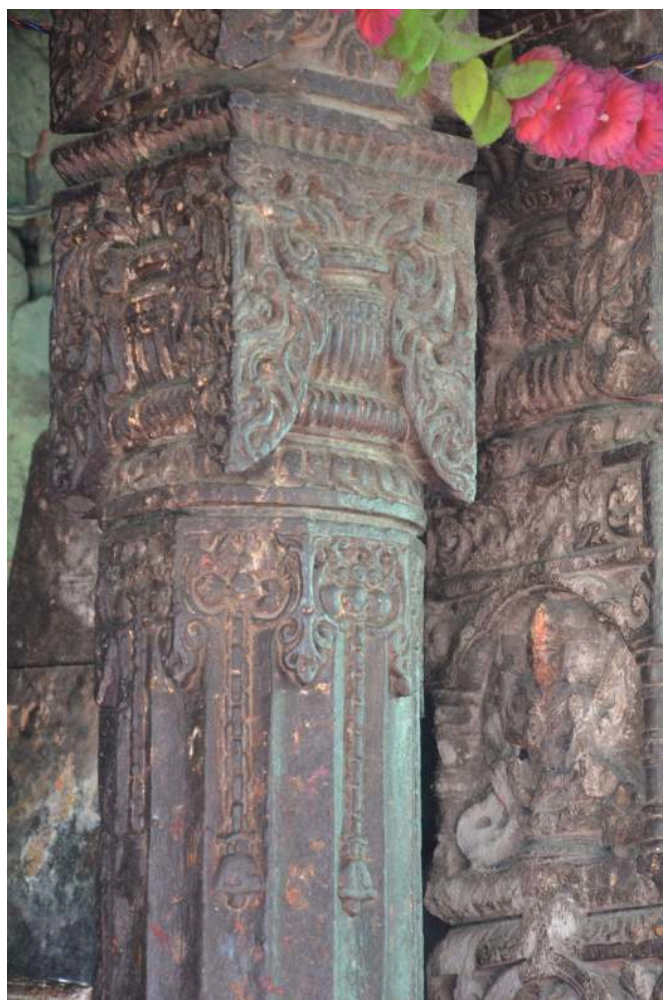

Note also the kîrttimukha images on the fluted columns. The Hari Rai temple is a rare example of a Chamba temple with fluted columns and compares most closely to the Triloknath temple in several respects

(c) Gerald Kozicz, 2016

\section{The sanctum}

The sanctum is filled with various ritual instruments and shows all signs of a living Himalayan temple serving both Buddhist and Hindu pilgrims. A gilded canopy is suspended from the lantern ceiling. The walls are blank and appear polished; a small niche in each of the lateral walls is the only element to interrupt the plain surface. The current main idol made of white marble is certainly not original ${ }^{22}$. To its left is another smaller black stone sculpture of the same deity - probably a predecessor of the white one (fig. 22). Depending on the affiliation of the pilgrim, either a Buddhist lama or a brahmin conducts the blessings. 
Figure 22. Sculptures of Sugatisamdarśana Lokeśvara inside the sanctum

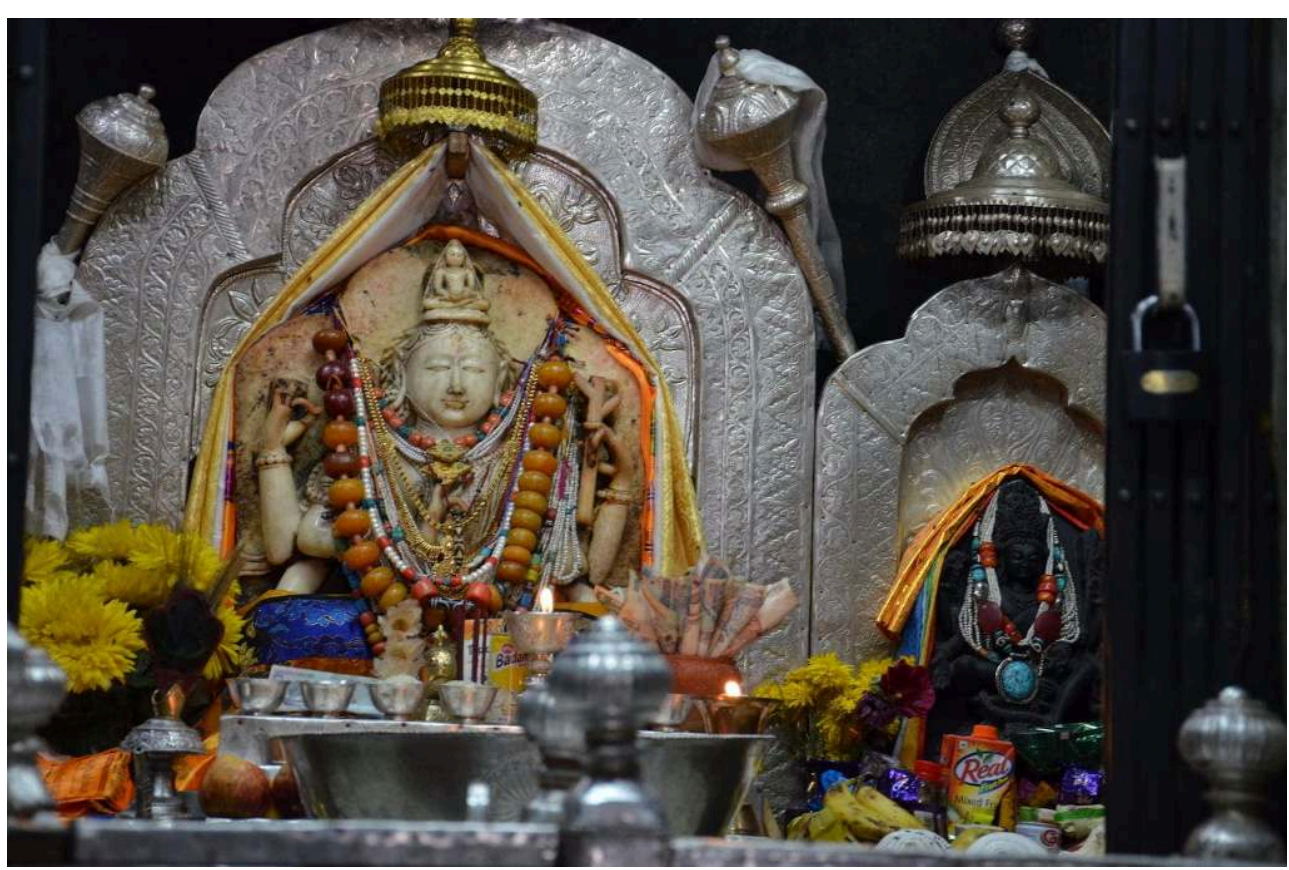

(c) Gerald Kozicz, 2016

As already noted by Maxwell, there is no trace of a Śiva lingam inside the sanctum ${ }^{23}$, but his assumption that it had been removed is not convincing. If there had been a lingam, it would have certainly been a quite massive one. Such lingams were placed on pedestals modelled after the female sexual organ (Skt. yoni pithas) and fixed to the temple foundations. A lingam is a phallic symbol. Its vertical form has three parts (fig. 23). The lowest part and the middle part have square and octagonal sections, and are usually integrated in the pedestal and therefore invisible. Only the upper-most third part of round sectional shape is what emerges from the yoni pitha. Accordingly, it is almost impossible to remove a lingam from its base or pedestal without destroying it. In a comparable case, the Śiva temple of Saho in Chamba was rebuilt around the existing lingam after the superstructure had been destroyed by a landslide (fig. 24). In the course of reconstruction, the temple was rebuilt around the lingam and it would not be possible to remove the lingam from the chamber without severely damaging the foundation - not to speak of the gate that would never allow for a passage of an idol of such size (fig. 25). 
Figure 23. A free-standing, complete lingam without pedestal displaying the three different sectional shapes

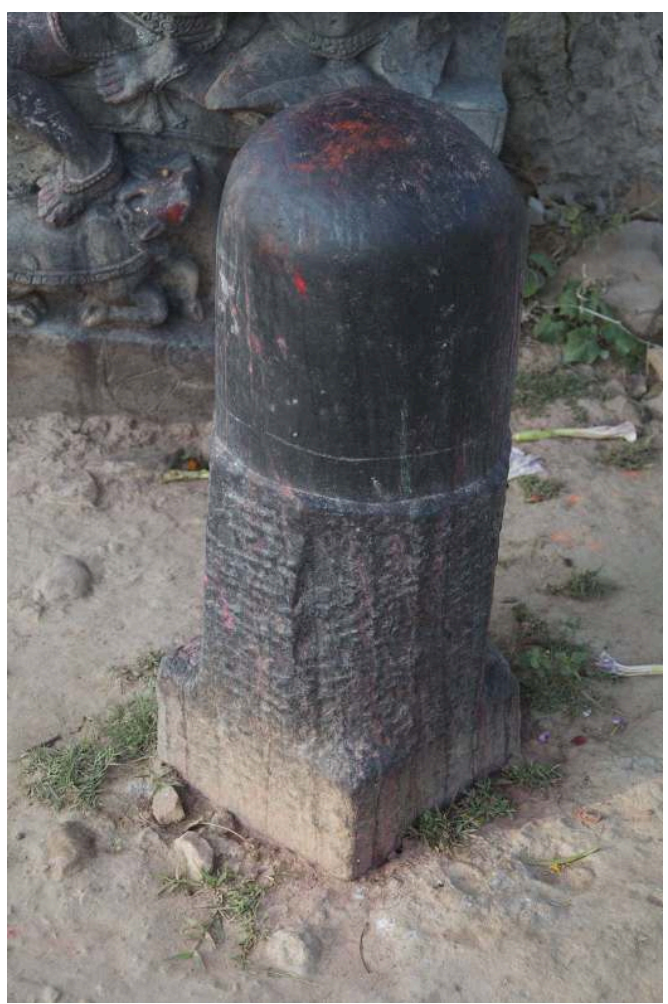

Only the lowest "square-shaped" part is below the surface (c) Gerald Kozicz, 2013 
Figure 24. The temple of Saho which originally was a classical nagara temple was rebuilt around the original lingam and covered by a wooden roof

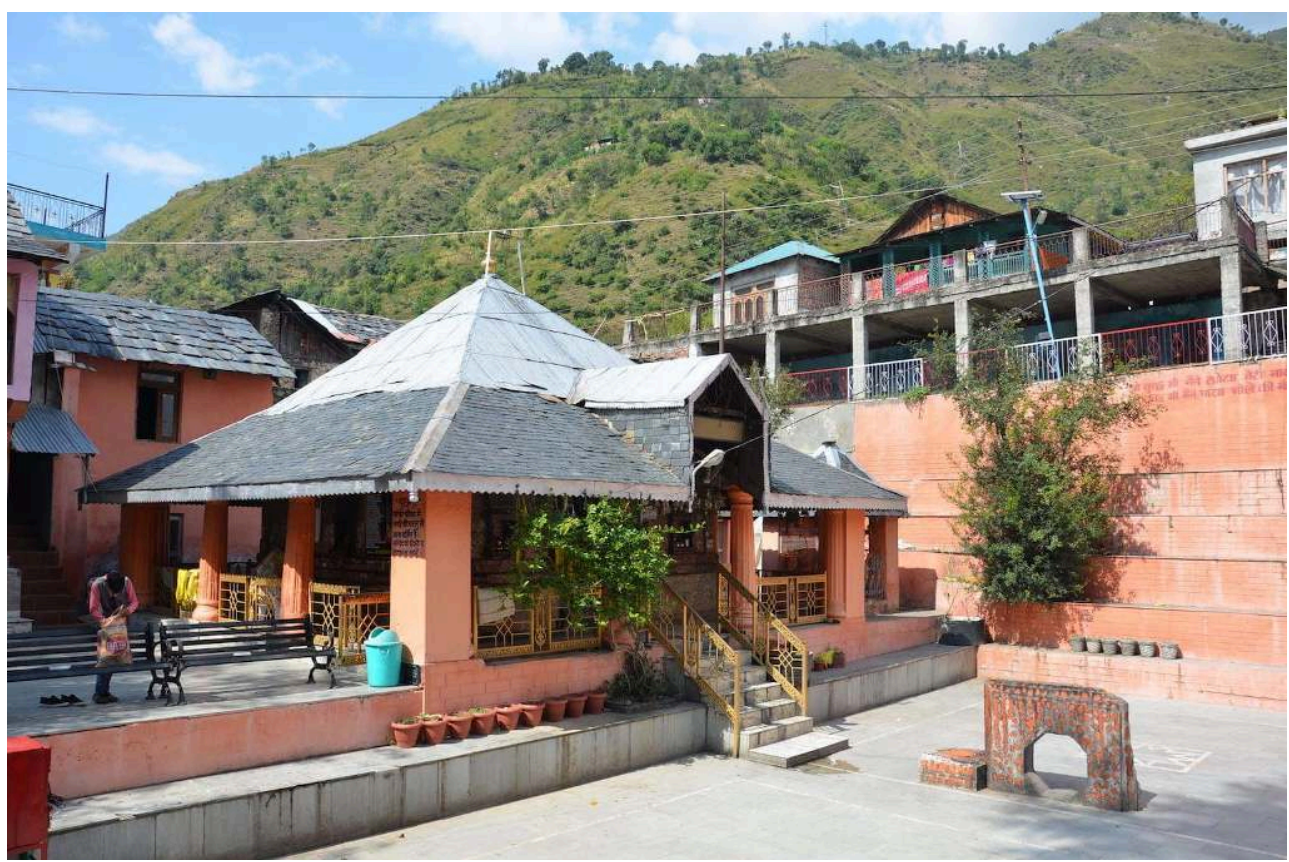

In front of the temple the middle part of a multi-layer pedestal of a now lost lingam was put in an unusual up-right position to allow worshippers to pass through it and gain religious merit and purification thereby

(c) Gerald Kozicz, 2018

Figure 25. The lingam inside the Saho temple is decorated with orange flowers and almost reaches into the lantern ceiling

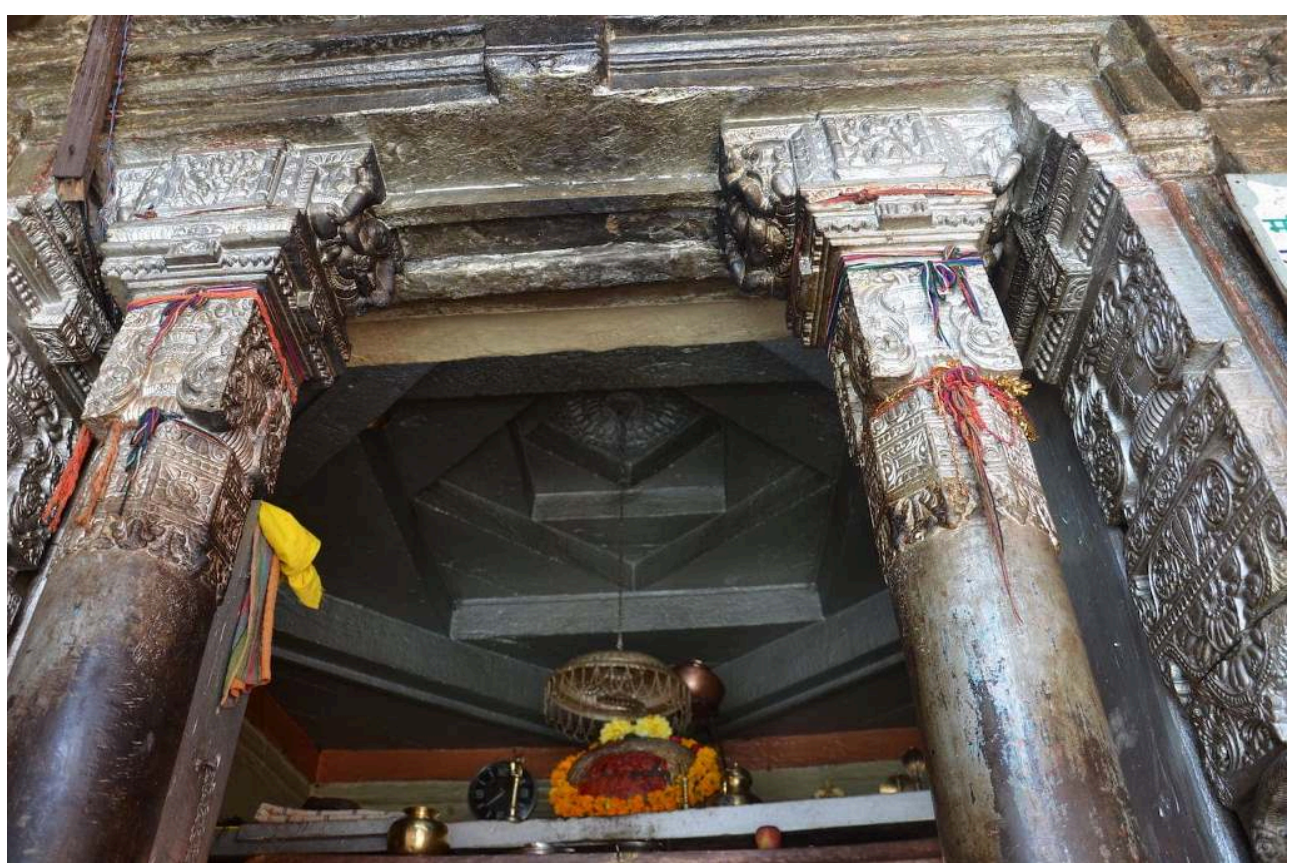

Note the silver paint on the original portal which has been re-used for the reconstruction of the temple (c) Gerald Kozicz, 2018 
Thus there had probably never been a lingam at Triloknath. The total lack of any trace of a lingam also supports the assumption that the pranala - at least in this regional context - is to be understood as a generic component of nagara architecture, and not as the marker of a Śiva temple.

\section{The shrine at the corner: another conundrum}

Behind the temple's northern corner, at a distance of less than two metres from its newly built corner, are the remains of a small shrine (fig. 26). This small replica of the large temple faces the same direction as the main temple-and shows the same architectural and iconographic inconsistencies and ambiguities. In the course of restoration works following the disastrous landslide of 1979, the structure was integrated into the newly built outer wall of the circumambulation, leaving less than half of it visible. As with the main sanctum, the shrine displays a number of deviations from the common pattern of comparable shrines in Kulu. In fact, we find the same distinction as already noticed with the bhadra niches of the main temple. In Kulu all the front roofs covering the open vestibule are frontally supported by two columns.

Figure 26. Shrine at the northwestern corner of the main temple

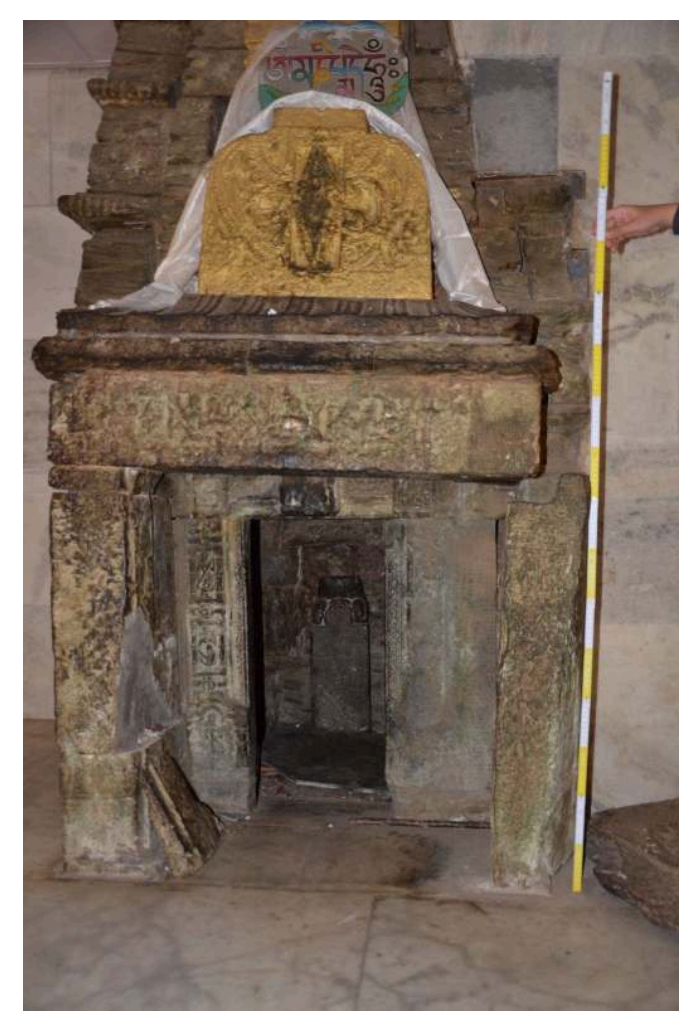

(c) Gerald Kozicz, 2016

By contrast, at Triloknath two lateral walls support the roof. Further, an additional slab is placed on those sidewalls, providing a full horizontal support for the actual roof slab. Such construction has not been noted elsewhere. In the centre of the frontal part of that horizontal slab on which the roof of the porch rests, a figure in lalitāsana can be seen. Despite its defaced state, Maxwell identifies this deity as Śiva, but the figure could 
also be Avalokiteśvara, who is frequently depicted in the same pose. The situation at the actual frame is similarly ambiguous. At the Kulu shrines dedicated to Śiva and Pārvatī, it was usually not Śiva but Ganeśa, their son, who was depicted on the central image of the first lintel. At this small shrine in Triloknath, the figure in this position is badly damaged and what is left is currently covered by a thick layer of butter and paint. Nevertheless, the proportions and size of what is presently visible would indicate a human head rather than an elephant head. The other parts of the doorframe also differ from the Kulu typology. While doorframes of all small Kulu shrines display only ornamental motifs besides the central image of the first lintel, the Triloknath shrine has a miniature doorframe with the full iconographic programme of a large-scale portal in condensed form.

The lower sections of the jambs display the remains of the two river deities. Fragments of human figures also survive above the river deities. The lintel is divided into five compartments. The central field is flanked by two kirttimukha that show remarkable stylistic differences from the same image in the centre of the architrave of the main temple (cf. fig. 7). While the latter is clearly based on the lion face, the kirttimukha of the shrine apparently has a beak above the jaw. It may be noted that both versions of kirttimukha heads can be found in the mural paintings of the Alchi Sumtsek in Ladakh, where they occur even in the same mandala ${ }^{24}$. However, in the context of nagara temple architecture, such beaks are a feature not noticed elsewhere so far.

At the far right of the lintel a male (?) figure is shown as if running towards the centre with slightly raised arms that hold a sort of scarf that is draped around his head. This feature recalls the directional protective deity (Skt. lökapāla) Vayu (fig. 27). The overall layout of the site supports this identification. The main temple is roughly oriented towards the east and the shrine is roughly at its northwestern corner, following Indian cosmology where Vayu holds the northwestern position. Therefore, the actual position exactly mirrors Vayu's directional affiliation within the directional system. 
Figure 27. The Wind God Vayu (?) on the lintel

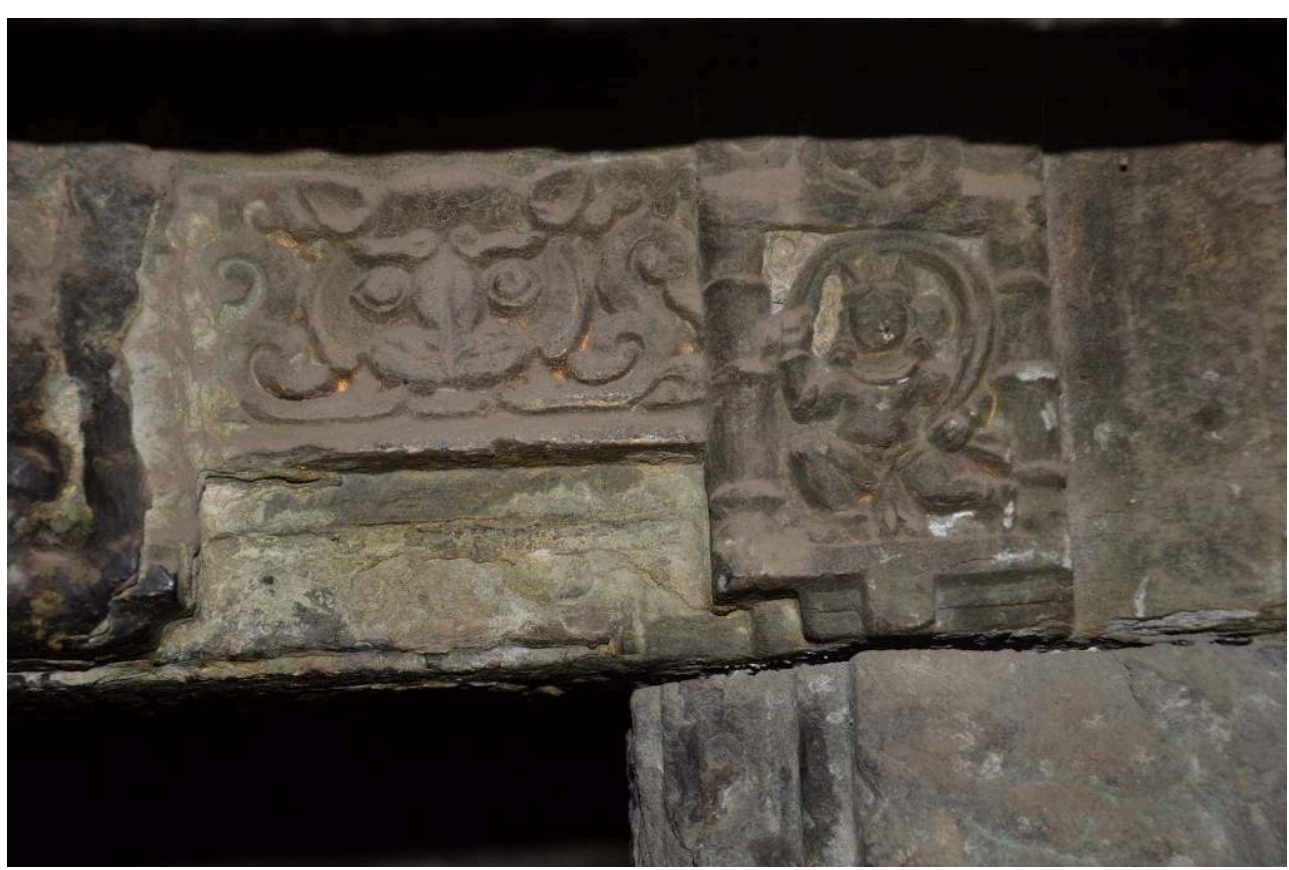

(c) Gerald Kozicz, 2017

If this hypothesis is accepted, could there originally have been four small shrines displaying the four pairs of directional protective deities in flanking positions of the respective lalätabimba? Early photographs only show one shrine at the northern side of the temple. However, this is the only position where a small shrine would have been protected by the main temple from landslides and avalanches. The shrines on the other sides of the temple would have been swept away by the avalanches and landslides that must have hit the site in the past. Unfortunately, recent building activities have completely erased all traces of former structures around the sanctum. Therefore, the hypothesis of a five-fold architectural set with the main sanctum in the centre remains uncertain until archaeological evidence comes to light.

\section{Conclusion}

The Triloknath temple is not only unique in terms of ritual practice but also regarding its structural and architectural features. The building differs significantly from nagara temples on the southern face of the Himalayan chain, which makes it difficult to fit the Triloknath temple into the timeline of Kulu and Chamba temples. The critical point is the unusual sikhara tower, in particular the plaster finishing. Today, its relevance is not that obvious because the roofing of the circumambulation corridor and the modern mandapa do not allow viewing the whole building. However, if the building is to be imagined without the roofed circumambulation space-and its other-modern additions, the picture displays a classical stone mandovara with a plain, white plastered sikhara. Such a combination would actually look not only unusual but even aesthetically unpleasant and wrong.

30 Why did the builders not continue with a stone structure similar to the models from the southern face of the Himalayan Range? For the time being the reasons for such 
inconsistency remains a matter of speculation. One explanation might be that the building process was interrupted and the craftsmen had to leave due to some change in the economic or political situation. Another, more likely scenario, would be repair works undertaken following a natural disaster. The difference in construction methods and the stone works between the mandovara and the sikhara support such a hypothesis. The Three Faces of Siva would certainly have been reused from the original structure and integrated in the new construction. However, such hypothesis remains tentative unless the Three Faces of Śiva can be cleared from the thick layer of whitewash and its structural joints with the actual tower be examined in detail.

But what does this mean for the analysis of the socio-religious background and the architectural history of the building? At this point, it is worth recalling Maxwell's remark on the lingam. The question that arises refers to the socio-cultural scenario rather than to an architectural perspective: under which circumstances could a Śiva lingam have been removed? There are no hints of a political power in the place that would have been that supportive of Buddhism. The removal of a lingam - if possible at all - would have been a forceful act and would have resulted in the destruction of the piece. Thus, it would have meant a most severe offence against the Śiva followers, and it may be doubted that the two religions would then have coexisted in such harmony as is found today.

According to the analysis of the central image of the first lintel, it appears that the temple was never completed. Since there are clues for both Buddhist and Śaiva affiliations among the original structural components of the building, the present state of research points towards the presence of both Buddhists and Hindus at the time of the completion of the construction process - and perhaps leaving the central image of the first lintel unfinished was a deliberate decision to open the sanctum for pilgrims of both faiths. Such a decision would also explain why both religions coexist even today not only in Triloknath but also in other sites in the region.

To summarise the conclusion: instead of an answer to the question about the original religion - Buddhist or Śaiva - a hypothetical explanation is brought forward as to why such an answer can hardly be given. From the available evidence, the architectural history of the Triloknath temple appears as a sequence of changes and a process that evidently began even during its construction and that has been continuing up to the present day. The result is a conundrum, a structure that today shows a surprising number of architectural modifications and changes, some of them hidden under more recent structural layers and therefore impossible to investigate on site.

\section{Acknowledgements}

This article resulted from fieldwork conducted in 2016, 2017 and 2018 within the framework of the Austrian Science Fund (FWF) Project 28509, located at the Institute for Architecture and Media of the Technical University Graz and funded by the Austrian Science Fund. The author would like to express his sincere gratitude to Vivek Bhatia, Deputy Commissioner of Keylong at the time of the 2016 survey, and Mrs. Maalvika Pathania, State Convenor of INTACH in Himachal Pradesh, for their support. This article would have not been possible without the comments and the contributions by Heinrich Pöll and Rob Linrothe. 


\section{BIBLIOGRAPHY}

Denwood, P. 2014 The dating of the Alchi Sumtsek, in E. Lo Bue \& J. Bray (eds) Art and Architecture of Ladakh. Cross-Cultural Transmission in the Himalayas and Karakorum (Leiden, Brill), pp. 159-166.

Goepper, R. \& J. Poncar 1996 Alchi. Ladakh's Hidden Buddhist Sanctuary, vol. 2, The Sumtsek (London, Serindia Publications).

Joshi, N. P. 1996 Tapasvinī Pārvatī (New Delhi, New Age International Limited Publishers).

Kozicz, G. in press, Temple III of Parahat, in A. Filligenzi (ed.), Proceedings of the $24^{\text {th }}$ Conference of the European Association for South Asian Art and Archaeology held in Naples, July 2018 (Naples).

Linrothe, R. (ed.) 2014 Collecting Paradise. Buddhist Art of Kashmir and Its Legacies (New York, Rubin Museum of Art/Mary and Leigh Block Museum of Art, Northwestern University Evanston).

Maxwell, T. 1980 Lākhamaṇdal and Trilokināth. The transformed functions of Hindu architecture in two cross-cultural zones of the Western Himalaya, Art International 24(1-2), pp. 9-74.

Rayner, H. in press, Early photographers in Ladakh 1860-1930, in Ch. Luczanits \& H. Poell (eds) Visible Heritage II. Essays on the Art and Architecture of Greater Ladakh (New Delhi, Studio Orientalia).

Sethi, S. M. \& H. Chauhan 2009 Temple Architecture of Chamba. Stone Temples, Sculptures and Fountain Stone Slabs (New Delhi, Indus Publishing Company).

Stutchbury, E. 1991 Rediscovering Western Tibet. Gonpa, Chorten and the Continuity of Practice with a Tibetan Community in the Indian Himalayas. PhD thesis (Canberra, The Australian National University) [online, URL: https://openresearch-repository.anu.edu.au/bitstream/ 1885/11288/1/Stutchbury_E.A._1991.pdf, accessed 14 October 2020].

Thakur, L. 1996 The Architectural Heritage of Himachal Pradesh (New Delhi, Munshiram Manoharlal Publishers).

Vogel, J. Ph. 1902 Triloknāth, Journal of the Asiatic Society of Bengal 71(1), pp. 35-41.

Widorn, V. 2007 The Mirkula Devi Temple in Udaipur, Lahau. A Wooden Jewel in the Western Himalaya and Its Role in the Sacred Landscape in Lahaul. PhD thesis (Vienna, University of Vienna).

Widorn, V. \& G. Kozicz 2012 The temple of Triloknath. A Buddhist Nāgara temple in Lahul, South Asian Studies 28(1), pp. 15-35.

\section{NOTES}

1. The history of Lahul is discussed in detail by Verena Widorn in her still unpublished PhD thesis (Widorn 2007). This work is currently in preparation for publication as a major monograph. I would like to thank Verena Widorn for her comments and for sharing some of her unpublished material.

2. See Linrothe 2014, pp. 36-39.

3. See Widorn \& Kozicz 2012.

4. See Maxwell 1980, pp. 52-54, fig. 39 (p. 53), fig. 40 (p. 54).

5. In the Buddhist perspective of the religious landscape of Lahul the two sites form a triad with Drilbu, the mountain at the confluence of the Chandra and the Bhaga. The plateau near the peak is considered a Cakrasamvara mandala representing the Mind, while Vajravārāhī of Udaipur 
represents the Body and Avalokiteśvara the Speech of the Buddha. See Widorn 2007, pp. 41-42 with reference to Stutchbury 1991, p. 64.

6. The first scholar who provided an analysis of the sculpture was J. Ph. Vogel (1902, pp. 36-41). Vogel identifies the image as a form of Avalokiteśvara, thereby ascertaining an earlier mention by the Rev. Mr. Heyde, the Moravian missionary based in Keylong.

7. Maxwell 1980, p. 52.

8. Widorn \& Kozicz 2012

9. See Widorn \& Kozicz 2012, pp. 29, 35, footnote 38 (p. 35).

10. See Denwood 2014, pp. 163-164.

11. See Maxwell 1980, p. 9, highlighting this practice at the very beginning of his discussion.

12. See Rayner, in press.

13. Sethi and Chauhan (2009, pp. 64-65) argue for a dating of the Hari Rai temple to the $2^{\text {nd }}$ half of the $11^{\text {th }}$ century on the basis of a copperplate inscription. They also argue for the current monument being a replacement of an earlier temple on the same spot due to the $8^{\text {th }}-9^{\text {th }}$ century dating of the sculpture enshrined in the temple. As a hint for the re-use of members of the original structure they particularly draw attention to the fluted pillars and other parts of the vestibule.

14. During the 2018 fieldwork the author noticed that even devoted worshippers of Viśnu were unaware of the iconographic meaning and religious nature of the three heads on the sukanasa. Obviously this iconic element was not even recognised. It is not possible to ascertain the period when its implementation as a pan-Hindu element in architecture began. However, the integration of these elements among the early temples points at the very early stage of stone temple architecture in the region.

15. For a detailed discussion of the portal and its proportional system see Widorn \& Kozicz 2012, pp. 26-27.

16. The size and ratio of the door frame was already noted in Thakur 1996, p. 57.

17. See Kozicz, in press.

18. Maxwell did not make any comment on the absence of any images in the lalatabimba.

19. See Widorn \& Kozicz 2012, pp. 28-29.

20. The portal was re-used and incorporated into the concrete structure of the new temple.

21. See e.g. Joshi 1996, pp. 26-27.

22. See Widorn \& Kozicz 2012, pp. 28-29, 32, and fig. 22 (p. 32, photograph by D. Lewiston, 1982). The muscular structure of the abdomen, the broad shoulders emerging from the slim waist and the facial features of the black sculpture clearly reflect the style of Kashmir. The white marble image lacks all these characteristics that might indicate an early date.

23. Maxwell 1980, p. 52.

24. See e.g. the Vajradhātumandala on the first floor published in Goepper \& Poncar 1996, p. 186.

\section{ABSTRACTS}

The Triloknath temple of Tunde in the Chandrabhaga valley of Lahul holds a special position among the religious monuments of the western Himalayan region. It is a place of Buddhist and Hindu worship. This unusual co-existence of the two religious belief systems results from a two- 
fold identification of the main cult image as Avalokiteśvara or Śiva. The article will address this situation from an architectural perspective.

Le temple de Triloknath à Tonde, dans la vallée de Chandrabhaga au Lahul, occupe une place particulière parmi les monuments religieux des régions de l'Himalaya occidental. C'est un lieu de culte hindou et bouddhique. Cette coexistence inhabituelle des deux religions découle d'une double identification de l'image principale soit en tant que Avalokiteśvara ou en tant que Śiva. Cet article adresse cette situation d'un point de vue architectural.

\section{INDEX}

Mots-clés: bouddhisme, Lahul, shivaïsme

Keywords: Buddhism, Lahul, Shaivism

\section{AUTHOR}

\section{GERALD KOZICZ}

The author has been in the leading position of several research projects funded by the Austrian Science Fund (FWF) since 2005. While the original focus of his research was on Himalayan Buddhist architecture, the recent projects also include Hindu architecture of the western Himalayan foothills or former hill states.

gerald.kozicz@gmx.at

https://iam.tugraz.at/nagara/ 